\title{
An LCA Study of an Electricity Coal Supply Chain
}

\author{
Chao Wang, Dong Mu \\ School of Economics and Management, Beijing Jiaotong University (China) \\ chaowang.bn@gmail.com, mudong.bjtu@gmail.com
}

Received: December 2013

Accepted: March 2014

\section{Abstract:}

Purpose: The aim of this paper is to provide methods to find the emission source and estimate the amount of waste gas emissions in the electricity coal supply chain, establish the model of the environmental impact (burden) in the electricity coal supply chain, detect the critical factor which causes significant environmental impact, and then identify the key control direction and reduce amount of environmental pollution in the electricity coal supply chain.

Design/methodology/approach: In this context, life cycle inventory and life cycle assessment of China's electricity coal were established in three difference stages: coal mining, coal transportation, and coal burning. Then the outcomes were analyzed with the aim to reduce waste gases emissions' environmental impact in the electricity coal supply chain from the perspective of sensitivity analysis.

Findings: The results and conclusion are as follow: (1) In terms of total waste gas emissions in electricity coal supply chain, $\mathrm{CO}_{2}$ is emitted in the greatest quantity, accounting for $98-99 \mathrm{wt} \%$ of the total waste gas emissions. The vast majority of the $\mathrm{CO}_{2}$, greater than $93 \%$, is emitted from the power plant when the coal is combusted. (2) Other than $\mathrm{CO}_{2}$, the main waste gas is $\mathrm{CH}_{4}, \mathrm{SO}_{2}$ and so on. $\mathrm{CH}_{4}$ is mainly emitted from Coal Bed Methane (CBM), so the option is to consider capturing some of the $\mathrm{CH}_{4}$ from underground mines for an alternative use. $\mathrm{SO}_{2}$ is mainly emitted from power plant when the coal is combusted. (3) The environmental burden of coal burning subsystem is greatest, followed by the coal mining subsystem, and finally the coal transportation subsystem. Improving the coal-burning efficiency of coal-fired power plant 
in electricity coal supply chain is the most effective way to reduce the environmental impact of waste gas emissions. (4) Of the three subsystems examined (coal mining, coal transportation, and coal burning), transportation requires the fewest resources and has the lowest waste gas emissions. However, the energy consumption for this subsystem is significant (excluding the mine mouth case), and transportation distance is found to have a substantial effect on the oil consumption and non-coal energy consumption. (5) In electricity coal supply chain, the biggest environmental impact of waste gas emissions is GWP, followed by EP, AP, POCP and ODP, and regional impact is greater than the global impact.

Practical implications: The model and methodology established in this paper could be used for environmental impact assessment of waste gas emissions in electricity coal supply chain and sensitivity analysis in China, and it could supply reference and example for similar researches. The data information on life cycle inventory, impact assessment and sensitivity analysis could supply theory and data reference for waste gas emissions control in electricity coal supply chain.

Originality/value: To the best of our knowledge, this is the first time to study the environmental influence of electricity coal supply chain by employing a LCA approach from life cycle of electricity coal.

Keywords: life cycle assessment; electricity coal supply chain; sensitivity analysis

\section{Introduction}

According to the official data from the National Bureau of Statistic (CSY, 2013), in 2012, the velocity of national electric power grows overwhelmingly in the recent years in China. And $81 \%$ of the electricity was produced from the coal-fired power plant (IEA, 2010). Therefore, coal plays a dominant role in China economic growth. Coal accounts for almost $90 \%$ of China's primary energy storage (Qiu, 2013) and accounts for about 70\% of China's primary energy production and consumption (Yan, 2006). Because of its abundance in proven reserves and its stability in supply, coal will continue to be a key component of primary energy mix in China at least over the next few decades (Li \& Leung, 2012). However, coal also accounts for a large share of $\mathrm{CO}_{2}$ emissions generated by anthropogenic activities, and based on Miao (2009) over $70 \%$ of total $\mathrm{SP}, 90 \%$ of $\mathrm{SO}_{2}, 67 \%$ of $\mathrm{NO}_{x}, 85 \%$ of $\mathrm{CO}_{2}$ produced by fossil fuels come from coal now. Therefore, in this carbon-constrained global world, understanding the environmental implications of producing electricity from coal life cycle is an important component of any policy to reduce total pollutants emissions. 
Electricity coal life cycle involves coal-mining, transportation and coal-burning process (Liu \& Zhao, 2011) which is also called electricity coal supply chain. It has seriously adverse effects on natural environment and human society. Main waste gas emissions includes $\mathrm{CO}_{2}, \mathrm{SO}_{2}, \mathrm{NO}_{x}$ and smoke dust, which could cause acid rain, ozonosphere damage and global warming after emission. Coal-mining process can result in overburden waste and slag heaps, mine fires (Mann \& Spath, 2001). The combustion of fuel for the coal transportation can result in air pollution, water pollution, traffic hazards etc. $\mathrm{SO}_{2}, \mathrm{NO}_{x}$ and particulate matters are released from the power plant in coal-burning process. However most researchers only give rise to the growing concern of the discharges and control methods of pollutants in coal burning process, not from the perspective of coal lifecycle, because of the high consumption of coal and high levels of waste emissions. Therefore, various measures have been taken to achieve better use of resources and energy as well as implement more sustainable practices in the coal-electricity system. Bates (1995), Uchiyama (1996), Restrepo, Miyake, Kleveston and Bazzo (2012) and Liang, Wang, Zhou, Huang, Zhou and Cen (2012) aimed at power plants in U.K, Japan, Brail and China respectively, studied the power plants' influence on environment with a Life Cycle Assessment (LCA) method. Pacca and Horvath (2002) calculated Global Warming Potential (GWP) of coal, gas, solar power and wind energy power plants. Hondo (2005) calculated greenhouse gas emission in eight power plants' construction, operation and retirement processes in Japan, using LCA method, process analysis and input-output analysis method. Kannan, Leong, Osman and Ho (2007) studied on five power plants and their influence on environment in Singapore from the point of power generation technology with LCA and LCC methods.

Lave and Freeburg (1973) found that comparison with petroleum and gas, coal has the most significant impact on environment in mining process, transportation process, as well as coalburning process. Hence, it is necessary to study the environmental influence of electricity coal from cycle life point. However, the literature on this aspect is rare. Pan and Mu (2011) compared the influence of nuclear power supply chain and electricity coal supply chain on health, environment and climate in China, with radiation effect from natural radioactive nuclides in coals as a indicator. Some researchers studies the environmental performance from natural gas (Korre, Nie \& Durucan, 2012), forestry (Björk, Erlandsson, Häkli, Jaakkola, Nilsson, Nummila et al., 2011), biofuel (You, Tao, Graziano \& Snyder, 2012). This paper studies an electricity coal supply chain by employing a LCA approach. The remainder of the present paper is organized as follows. Section 2 gives a brief introduction of a specific electricity coal supply chain in China. Section 3 studies this electricity coal supply chain with LCA. Methods of sensitivity analysis are presented in Section 4. Finally, conclusions are drawn in Section 5. 


\section{The case study}

The electricity coal supply chain involves the coal mining process, coal transportation process and coal burning process, all based in China. The goal of coal mining is to remove coal from the ground. After coal preparation/cleaning, coal is moved to the coal-fired power plant by barge, rail or truck. This paper presents a thorough case study of the environmental impact of waste gas emissions in an electricity coal supply chain, where the coal is mined by an underground colliery- Jiangzhuang Coal Mine (JZCM) of Zaozhuang Coal Mining Group Co.,Ltd. and is transported $93 \mathrm{Km}$ by heavy-truck and then burned at Shiliquan Plant (SLQP) of Zaozhuang which is a coal-fired power plant.

\subsection{Coal mining process}

Underground mining operations include: cutting, drilling, blasting, loading, and hauling. Auxiliary operations include ventilation, drainage, power, communications, and lighting. Roof support is another task which is considered to be a unit operation. The raw coal output of JZCM was 3.4 million tons in 2012 . In the same year, it used 1.81 million $\mathrm{m}^{3}$ fresh water, 0.44 thousand tons of diesel oil, 0.086 thousand tones of petrol, 9.87 thousand tons of steel, 19.7 thousand tons of cement and 1.74 thousand $\mathrm{m}^{3}$ of timber. The energy consumption includes 7.23 million kWh of electricity and 13.2 thousand tons of coal. It produced waste comprising 0.461 million tons of coal gangues, 0.235 million tons of washed gangue, 0.168 million tons of coal slurry, 1.78 million tons of mining wastewater and other waste. Table 1 gives the underground mining equipment fuel and material requirement, and Table 2 gives a breakdown of the electrical details. The research result of Clean Production Standard in Coal Washing and Processing Industry (2010) shows that electricity consumption of raw coal production in state-owned key coal mines usually ranges between $15 \mathrm{kWh} / \mathrm{t}$ and $25 \mathrm{kWh} / \mathrm{t}$, and the rock bottom electricity consumption reaches $4.4 \mathrm{kWh} / \mathrm{t}$.

\begin{tabular}{|l|c|c|c|c|c|}
\hline \multicolumn{1}{|c|}{ Fuel/material } & Application amount & Unit & Fuel/material & Application amount & Unit \\
\hline Electricity & $2.13 \mathrm{E}+01$ & $\mathrm{KWh}$ & Petrol & $2.54 \mathrm{E}-05$ & $\mathrm{t}$ \\
\hline Coal & $3.88 \mathrm{E}-03$ & $\mathrm{t}$ & Steel & $2.90 \mathrm{E}-03$ & $\mathrm{t}$ \\
\hline Fresh water & $5.32 \mathrm{E}-01$ & $\mathrm{~m}^{3}$ & Cement & $5.65 \mathrm{E}-03$ & $\mathrm{t}$ \\
\hline Diesel oil & $1.30 \mathrm{E}-04$ & $\mathrm{t}$ & Timber & $5.11 \mathrm{E}-04$ & $\mathrm{~m}^{3}$ \\
\hline
\end{tabular}

Table 1. Underground mining equipment fuel and material requirement (Unit: /t of raw coal) 


\begin{tabular}{|l|c|c|c|c|c|}
\hline \multirow{2}{*}{\begin{tabular}{l}
\multirow{2}{*}{ Equipment } \\
Longwall unit
\end{tabular}} & Total(kW) & Hours used/day & \multirow{2}{*}{ Load (kW) } & \multicolumn{2}{c|}{ Electrical consumption } \\
\cline { 3 - 6 } & 1860 & 16 & 1860 & 29.76 & 21.4 \\
\hline Continuous miner & 890 & 10 & 890 & 8.90 & 6.1 \\
\hline Loading machine & 245 & 10 & 245 & 2.45 & 2.9 \\
\hline Shuttle car & 423 & 10 & 423 & 4.23 & 3.1 \\
\hline Roof bolter & 85 & 12 & 85 & 1.02 & 0.8 \\
\hline Ratio feeder & 196 & 10 & 197 & 1.96 & 1.8 \\
\hline Triple-rock duster & 70 & 12 & 70 & 0.84 & 0.7 \\
\hline Auxiliary fan & 25 & 18 & 25 & 0.45 & 0.4 \\
\hline Supply car & 209 & 12 & 209 & 2.51 & 1.7 \\
\hline Conveyor & 596 & 16 & 596 & 9.54 & 7.3 \\
\hline Ventilation fan & 375 & 24 & 375 & 9.00 & 6.9 \\
\hline Pumps, bolting & 315 & 10 & 315 & 3.15 & 3.0 \\
\hline Lighting & N/A & 24 & 268 & 6.43 & 4.8 \\
\hline
\end{tabular}

Table 2. Underground mining electrical requirements

In this case, coal preparation/cleaning is a part of coal mining process in JZCM. Coal preparation normally involves size reduction of the mined coal, the removal of ash-forming materials and rocks, as well as the removal of very fine coal. Coal preparation methods include the gravity method, floatation, magnetic separation and electro-separation. The JZCM uses the gravity method. The coal and detrimental impurities can be separated by weight differences of the coal and the waste in both water and air. In this process, the coal floats on the surface and the detrimental impurities submerge to the bottom. And then coal is shipped to coal-fired power plants, while the waste are used for filling. The coal preparation process includes screening, crushing, separating, dewatering, storing and loading. Screening is to identify the constitution of different raw coal particles. Crushing is to grind the mined coal blocks into coal power. Separating is to classify coal particles according to their size, and to separate mineral particles from the coal. Dewatering is to remove water from the coal. Storing and loading is to store the cleaned coal, load it and then ship it to the coal-consuming enterprises. The preparation process and coal preparation equipment requirements are shown in Table 3, and the coal preparation fuel and material requirements are presented in Table 4. According to Clean Production Standard in Coal Washing and Processing Industry (2010), energy demand for washing 1 ton of coal in large coal preparation plant is less than $10 \mathrm{kWh}$, and the lowest energy consumption is less than $5 \mathrm{kWh}$. 


\begin{tabular}{|l|l|}
\hline \multicolumn{1}{|c|}{ Techniques Process } & \multicolumn{1}{c|}{ Equipment } \\
\hline Screening & Screen grader \\
\hline Crushing & Crusher \\
\hline Jig washing & Jigger, heavy-media separator, heavy medium cyclone \\
\hline Dewatering & Dewatering centrifuge \\
\hline Loading & Truck, crane \\
\hline
\end{tabular}

Table 3. Coal preparation equipment requirements

\begin{tabular}{|l|c|c|}
\hline \multicolumn{1}{|c|}{ Fuel/material } & Requirement & Unit \\
\hline Coal & 1.31 & ton \\
\hline Electricity & 32.4 & $\mathrm{MJ}$ \\
\hline Water & 1278 & $\mathrm{Kg}$ \\
\hline Manganese $(\mathrm{Mn})$ & 1.593 & $\mathrm{Kg}$ \\
\hline
\end{tabular}

Table 4. Coal preparation fuel and material requirement (Unit: /of ton MAF raw coal)

\subsection{Coal transportation process}

In China, the main transportation methods are railways, highways and waterways. In the coal transportation process, this paper only considers coal that is transported from the coal mine to the power plant. Ammonium nitrate and other blasting materials which are transported to the coal mine, and ammonia $\left(\mathrm{NH}_{3}\right)$, hydrogen chloride $(\mathrm{HCl})$, sodium hydroxide $(\mathrm{NaOH})$, calcium carbonate $\left(\mathrm{CaCO}_{3}\right)$, etc, which are transported to the power plant are not included in the LCA. According to the investigation, from JZCM to SLQP, the coal is shipped by steyr-king heavy duty trucks which have a loading capacity of 24 tons. The distance is $93 \mathrm{Km}$, the total diesel fuel consumption is $36 \mathrm{~L}$, and the transportation routing is presented in Figure 1.

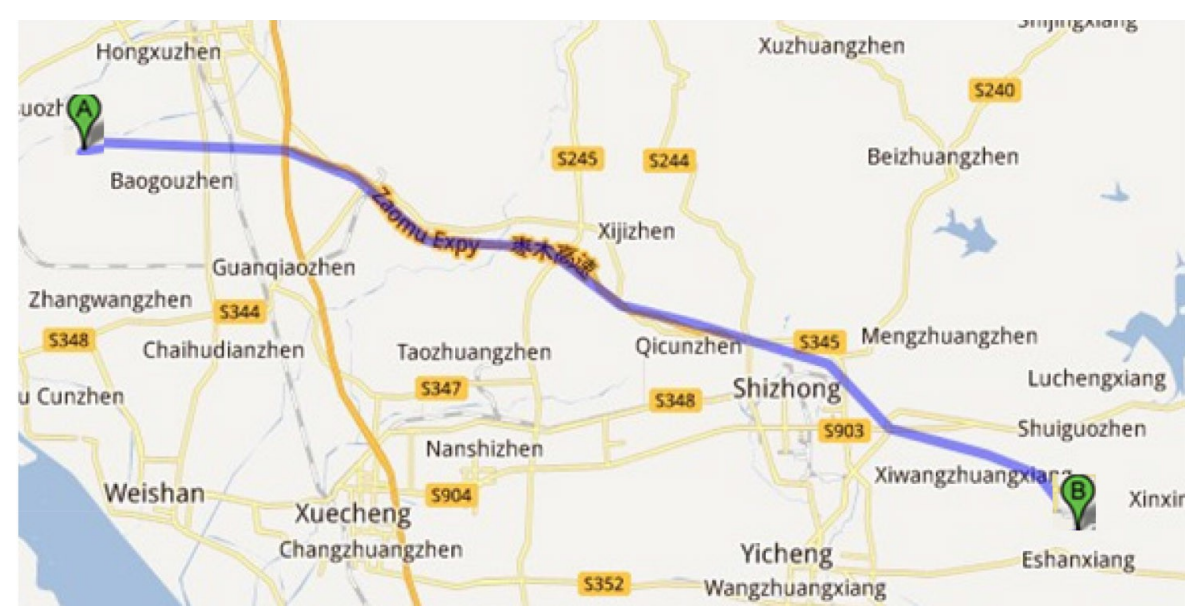

Figure 1 . Transportation routing of the electricity coal supply chain 


\subsection{Coal burning process}

The burning process occurred in coal-fired power plants, and data collected from SLQP are as show below. The total installed capacity is $1225 \mathrm{MW}$, and the power generation is 8.39 billion kW. In 2012, SLQP consumed 1.91 million tons of raw coal, 1.62 million tons of coal gangue, 2.76 million tons of coal slurry, and 58.30 million tons of fresh water. The power plant inventory includes energy and non-energy (material) demand (See Table 5).

\begin{tabular}{|c|c|c|c|}
\hline Number of generators & 4 & Raw coal & 227 (g/KWh) \\
\hline Installed capacity & $1225(\mathrm{MW})$ & Diesel & $194(\mathrm{~g} / \mathrm{KWh})$ \\
\hline Installation time & Apr. 1995 & Fresh water & $6.94 \mathrm{E}-03(\mathrm{~g} / \mathrm{KWh})$ \\
\hline Efficiency & $32 \%$ & Electricity & $1.16 \mathrm{E}-01(\mathrm{KWh})$ \\
\hline Fuel type & Lean coal & Water consumption & 33595 (t/day) \\
\hline Ammonia water & N/A (g/KWh) & Cooling water & $56000(\mathrm{t} / \mathrm{h})$ \\
\hline Coal slurry & $329(\mathrm{~g} / \mathrm{KWh})$ & Power capacity & 8.29 (GWh) \\
\hline Coal gangue & $192(\mathrm{~g} / \mathrm{KWh})$ & Pollution control system & ESP \\
\hline Middlings & $65.4(\mathrm{~g} / \mathrm{KWh})$ & Generator life expectancy & 30 (year) \\
\hline Pollution control equipment & ESP & Generator type & Pulverized coal boiler \\
\hline Fuel properties & \multicolumn{3}{|c|}{ Low Calorific Value $=22675 \mathrm{KJ} / \mathrm{Kg}$, Sulf concent $=1.24 \%$, ash concent $=26.82 \%$} \\
\hline
\end{tabular}

Table 5. Power plant inventory

\section{Life cycle analysis of the electricity coal supply chain}

An LCA approach is adopted to investigate the cumulative environmental burden produced by the supply chain generating $1 \mathrm{kWh}$ of electricity (reference flow).

\subsection{Goal and scope definition}

The overall objectives of the LCA study are to:

- Demonstrate the usefulness of the LCA method in measuring the environmental impacts of a defined electricity coal supply chain system.

- Provide an overall understanding of an electricity coal supply chain and the associated environmental burden involved in the main processes of the supply chain.

- Seek quantitatively the most effective way to reduce the environmental burden of waste gas emissions. 
- Highlight important areas for future research (further LCA studies concerning coal cinder utilization and the cost factor).

The scope of the LCA study (system boundary) is defined as follows: The system starts with the mining of coal and ends with electricity as the product. The main processes are the coal mining process, coal transportation process and coal burning process. The power plant which supplies energy to the supply chain is included in the system.

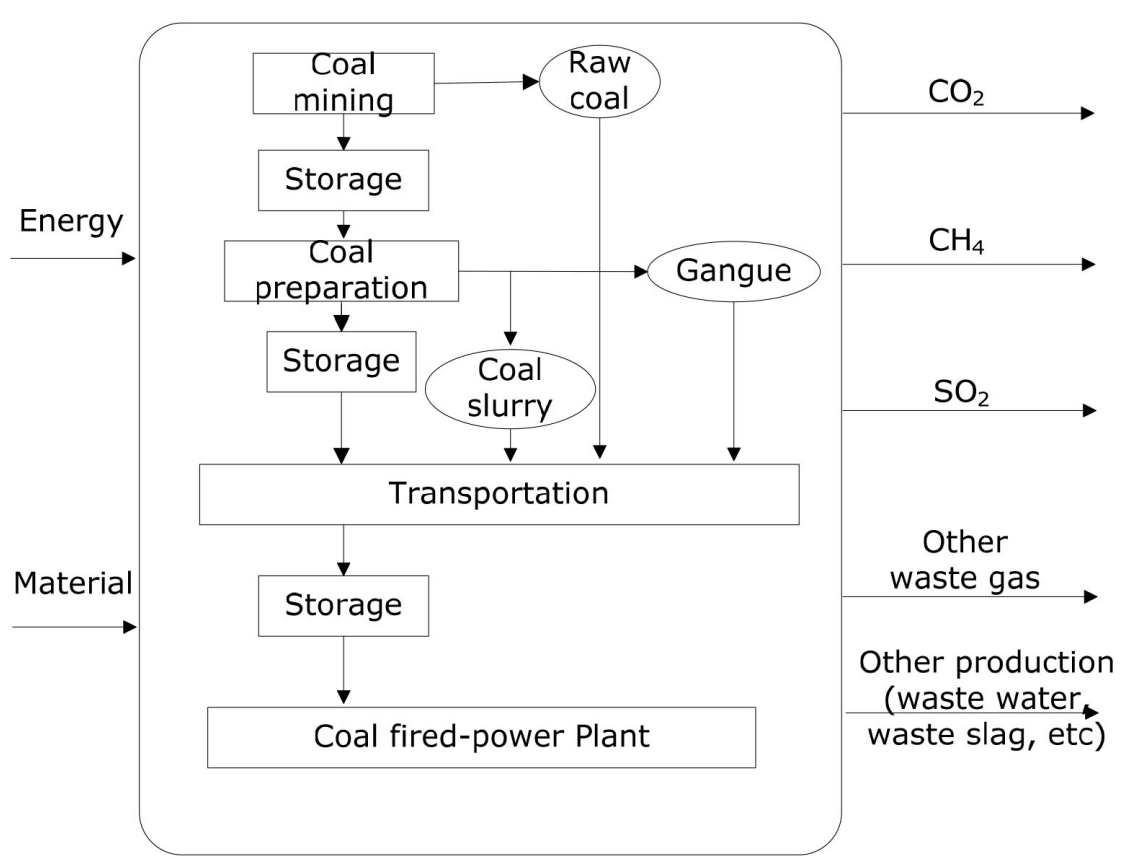

Figure 2. System boundary of the electricity coal supply chain

Based on the scope of the LCA, the supply chain model is displayed in Figure 2. The model represents a "Mining to Products (MTP)" system as distinct from a "Cradle to Grave" system. This means that coal's end of life (recycling) is not included in the study.

\subsection{Life cycle inventory ( $\mathrm{CCI}$ )}

\subsubsection{Main processes}

The LCI of the waste gas emissions released by the system are shown in Appendix A. All the results are based on the reference flow of $1 \mathrm{kWh}$ of electricity. 


\subsubsection{Coal mining process}

In the coal mining process, a lot of waste gases will be released. For example, greenhouse gases like $\mathrm{CO}_{2}$ and $\mathrm{CH}_{4}$ will be released during the coal mining process, and gases like $\mathrm{CO}_{2}, \mathrm{SO}_{2}$, $\mathrm{CO}$ and $\mathrm{H}_{2} \mathrm{~S}$ will be spontaneously released from coal gangues. The mining process has great effects on the regional ecological environment, with the major sources of waste gases being the mine ventilation process, coal gangue, and the coal preparation process. All emissions of waste gases in the mining process are listed in Appendix A.

\subsubsection{Coal transportation process}

The atmospheric environmental problems arising in the coal transportation process are mainly caused by the burning of transport fuels, spontaneous combustion of coal in the process of transportation and coal dust pollution near the transport route. Main waste gases consist of $\mathrm{HC}, \mathrm{CO}, \mathrm{NO}_{\mathrm{x}}, \mathrm{SO}_{2}$ and $\mathrm{H}_{2} \mathrm{~S}$. Considering the coal transport from JZCM to SLQP by heavy duty trucks, all emissions of waste gases in the coal transportation process are listed in Appendix $A$.

\subsubsection{Coal burning process}

The coal-fired power plants in coal burning process often burn large quantities of low grade coal with high sulfur and high ash, even coal gangues, and are adjudged as the greatest sources of waste gases in China. Waste gases from burning mainly contain $\mathrm{CO}_{2}, \mathrm{SO}_{2}, \mathrm{CO}$ and $\mathrm{NO}_{x}$. The direct consequence is that smoke dust and $\mathrm{SO}_{2}$ emissions are dominant among emissions from industrial various sectors in China (Zhao, Wang, Nielsen, Li \& Hao, 2010). In fact, the emissions of $\mathrm{SO}_{2}$ from coal and electricity account for more than $59 \%$ of the emissions in Controlled Zones for Acid rain and Sulfur Dioxide (Lu, Streets, Zhang, Wang, Carmichael, Cheng et al., 2010). All emissions of waste gases in the coal burning process are listed in Appendix A.

\subsubsection{Interpretation of LCI}

Appendix A represents waste gas emissions in the coal mining process, coal transportation process and coal burning process in the electricity coal supply chain. It is seen that:

- In terms of total air emissions, $\mathrm{CO}_{2}$ is emitted in the greatest quality, accounting for $98.8 \%$ wt $\%$ of the total air emissions for all processes examined. The vast majority of $\mathrm{CO}_{2}$, about $93.6 \%$, is emitted from the power plant when the coal is combusted. (See Table 6) 
- Excluding the $\mathrm{CO}_{2}$, the main waste gases emissions in the electricity coal supply chain are displayed in Table 6 . The largest proportion of the main waste gases is $\mathrm{CH}_{4}$, because JZCM is a high gas mine which releases $200 \mathrm{~m}^{3} \mathrm{CH}_{4}$ from CBM in producing one ton of coal. $\mathrm{SO}_{2}$ mainly comes from the coal burning process. Because there is no denitrification process in SLQP, the percentage of $\mathrm{NO}_{x}$ in the burning process, mining process and transportation process is $66.5 \%, 28 \%$ and $5.56 \%$ respectively.

\begin{tabular}{|c|c|c|c|c|c|}
\hline \multirow{3}{*}{ Process in electricity supply chain } & \multirow{2}{*}{\multicolumn{2}{|c|}{$\mathrm{CO}_{2}$}} & \multicolumn{3}{|c|}{ Other mainly waste gas } \\
\hline & & & \multirow{2}{*}{$\begin{array}{c}\mathrm{CH}_{4} \\
(\mathrm{~g} / \mathrm{KWh})\end{array}$} & \multirow{2}{*}{$\begin{array}{c}\mathrm{SO}_{2} \\
(\mathrm{~g} / \mathrm{KWh})\end{array}$} & \multirow{2}{*}{$\frac{N_{x}}{(g / K W h)}$} \\
\hline & (g/KWh) & $(\%)$ & & & \\
\hline Coal mining process $(\mathrm{g} / \mathrm{KWh})(\mathrm{a})$ & 50.328 & 5.17 & $3.58 \mathrm{E}+00$ & $4.01 \mathrm{E}-01$ & 3.67E-01 \\
\hline Coal transportation process $(\mathrm{g} / \mathrm{kWh})(\mathrm{b})$ & 11.981 & 1.23 & $1.93 \mathrm{E}-04$ & 7.98E-02 & $2.64 \mathrm{E}-03$ \\
\hline Coal burning process ( $\mathrm{g} / \mathrm{KWh})(\mathrm{c})$ & 910.22 & 93.6 & $3.72 \mathrm{E}+00$ & $9.54 \mathrm{E}-01$ & $8.20 \mathrm{E}-01$ \\
\hline Sum (g/KWh) & 972.53 & 100 & 7.30 & 1.43 & 1.19 \\
\hline
\end{tabular}

Note:

(a) Mining process is the underground mining process of JZCM;

(b) Transportation process is that coal is transported $93 \mathrm{Km}$ by truck from JZCM to SHQP;

(c) Burning process is that coal is burned by SHQP.

Table 6. Main waste gas emissions

\subsection{Impact assessment and discussion}

GaBi 4 Education software (PE Intentional, 2011) is used to carry out the impact assessment stage of the case study. Gabi 4's CML 2001 is adopted to calculate the following environmental impacts: (i) Global Warming Potential (GWP), (ii) Eutrophication Potential (EP), (iii) Photochemical Oxidants Creation Potential (POCP), (iv) Acidification Potential (AP), (v) Ozone Depletion Potential (ODP). The impact assessment method consists of three steps: characterization, normalization and final weighted scores.

\subsubsection{Characterization}

In this step, the LCI data are sorted into "classes" or environmental impact categories according to the effect they have on the environment. For example, $\mathrm{CO}_{2}$ will be classified under Global Warming Potential. Within each "class", the emissions are aggregated to produce an effect score. 


\subsubsection{Global Warming Potential}

Global Warming Potential (GWP) is derived by summing the emissions of the GHG multiplied by their respective GWP factors. The gases that contribute to Global Warming Potential are mainly $\mathrm{CO}, \mathrm{CO}_{2}, \mathrm{CH}_{4}$, and $\mathrm{N}_{2} \mathrm{O}$. GWP in the electricity coal supply chain is calculated in Table 7. In the coal life cycle, GWP mainly occurs in the coal burning process. So reducing the emissions of $\mathrm{CO}_{2}$ and $\mathrm{N}_{2} \mathrm{O}$ in the coal burning process is the main approach to decrease GWP in the electricity coal supply chain.

\begin{tabular}{|c|c|c|c|c|c|c|c|c|c|}
\hline \multirow[b]{2}{*}{ Stressors } & \multicolumn{3}{|c|}{ Mining Process } & \multicolumn{3}{|c|}{$\begin{array}{l}\text { Transportation } \\
\text { Process }\end{array}$} & \multicolumn{3}{|c|}{ Burning Process } \\
\hline & $\mathrm{CO}_{2}$ & $\mathrm{CH}_{4}$ & $\mathrm{~N}_{2} \mathrm{O}$ & $\mathrm{CO}_{2}$ & $\mathrm{CH}_{4}$ & $\mathrm{~N}_{2} \mathrm{O}$ & $\mathrm{CO}_{2}$ & $\mathrm{CH}_{4}$ & $\mathrm{~N}_{2} \mathrm{O}$ \\
\hline Amount & 50.33 & 3.58 & 0.00 & 11.98 & 0.19 & 0.00 & 910.22 & 0.04 & 0.04 \\
\hline Normalization $\mathrm{g} \mathrm{CO}_{2}$-Equiv. & 50.33 & 89.38 & 0.22 & 11.98 & 4.83 & 0.09 & 910.22 & 93.07 & 11.72 \\
\hline Normalization $\mathrm{g} \mathrm{CO}_{2}$-Equiv. (Process) & \multicolumn{3}{|c|}{139.93} & \multicolumn{3}{|c|}{16.90} & \multicolumn{3}{|c|}{922.87} \\
\hline $\begin{array}{l}\text { Normalization } \mathrm{g} \mathrm{CO}_{2} \text {-Equiv. } \\
\text { (Electricity Coal Supply Chain) }\end{array}$ & \multicolumn{9}{|c|}{1079.71} \\
\hline
\end{tabular}

Note: Data in above table rounded off to two decimals.

Table 7. GWP of waste gases in electricity coal supply chain ( $g / K W h$ )

\subsubsection{Eutrophication Potential}

Eutrophication Potential (EP) is defined as the potential of nutrients to cause over-fertilization of water and soil which in turn can result in increased growth of biomass. EP in the electricity coal supply chain is calculated in Table 8. In the coal life cycle, EP mainly occurs in the coal burning process. So reducing the emissions of $\mathrm{NH}_{3}$ and $\mathrm{NOx}$ in the coal burning process is the main approach to decrease EP in the electricity coal supply chain.

\begin{tabular}{|l|c|c|c|c|c|c|}
\hline & \multicolumn{2}{|c|}{ Mining Process } & Transportation Process & \multicolumn{2}{c|}{ Burning Process } \\
\hline Stressors & $\mathrm{NH}_{3}$ & $\mathrm{NO}_{x}$ & $\mathrm{NH}_{3}$ & $\mathrm{NO}_{x}$ & $\mathrm{NH}_{3}$ & $\mathrm{NO}_{x}$ \\
\hline Amount & $2.50 \mathrm{E}-04$ & $4.01 \mathrm{E}-01$ & $0.00 \mathrm{E}+00$ & $7.98 \mathrm{E}-02$ & $6.31 \mathrm{E}-03$ & $9.54 \mathrm{E}-01$ \\
\hline Normalization g Phosphate -Equiv. & $8.75 \mathrm{E}-05$ & $5.22 \mathrm{E}-02$ & $0.00 \mathrm{E}+00$ & $1.04 \mathrm{E}-02$ & $2.21 \mathrm{E}-03$ & $1.24 \mathrm{E}-01$ \\
\hline Normalization g Phosphate -Equiv. (Process) & \multicolumn{7}{|c|}{$5.23 \mathrm{E}-02$} & \multicolumn{5}{|c|}{$1.04 \mathrm{E}-02$} & $1.26 \mathrm{E}-01$ \\
\hline $\begin{array}{l}\text { Normalization g Phosphate -Equiv. } \\
\text { (Electricity Coal Supply Chain) }\end{array}$ & \multicolumn{5}{|c|}{$1.89 \mathrm{E}-01$} \\
\hline
\end{tabular}

Note: Data in above table rounded off to two decimals.

Table 8 . EP of waste gases in electricity coal supply chain $(\mathrm{g} / \mathrm{KWh})$ 


\subsubsection{Photochemical Oxidants Creation Potential}

Photochemical Oxidants Creation Potential (POCP) is related to the potential for VOCs and oxides of nitrogen to generate photochemical or summer smog. It is usually expressed relative to the POCP classification factor for ethylene. POCP in the electricity coal supply chain is calculated in Table 9. In the coal life cycle, POCP mainly occurs in the coal mining process. So reducing the emissions of $\mathrm{CH}_{4}, \mathrm{CO}$ and NMVOC in coal mining process is the main approach to decrease POCP in the electricity coal supply chain.

\begin{tabular}{|c|c|c|c|c|c|c|c|c|c|}
\hline & \multicolumn{3}{|c|}{ Mining Process } & \multicolumn{3}{|c|}{ Transportation Process } & \multicolumn{3}{|c|}{ Burning Process } \\
\hline Stressors & $\mathrm{CH}_{4}$ & $\mathrm{CO}$ & NMVOC & $\mathrm{CH}_{4}$ & $\mathrm{CO}$ & NMVOC & $\mathrm{CH}_{4}$ & $\mathrm{CO}$ & NMVOC \\
\hline Amount & $\begin{array}{l}3.58 \\
E+00\end{array}$ & $\begin{array}{l}1.11 \\
E-01\end{array}$ & $\begin{array}{l}3.24 \\
E-02\end{array}$ & $\begin{array}{l}1.93 \\
E-01\end{array}$ & $\begin{array}{l}1.90 \\
\mathrm{E}-02\end{array}$ & $\begin{array}{l}3.21 \\
\mathrm{E}-03\end{array}$ & $\begin{array}{l}3.72 \\
\mathrm{E}-02\end{array}$ & $\begin{array}{l}1.68 \\
E-01\end{array}$ & $\begin{array}{l}2.35 \\
E-02\end{array}$ \\
\hline $\begin{array}{l}\text { Normalization g Ethene } \\
\text {-Equiv. }\end{array}$ & $\begin{array}{l}2.15 \\
\mathrm{E}-02\end{array}$ & $\begin{array}{l}3.01 \\
\mathrm{E}-03\end{array}$ & $\begin{array}{l}1.18 \\
\mathrm{E}-02\end{array}$ & $\begin{array}{l}1.16 \\
\mathrm{E}-03\end{array}$ & $\begin{array}{l}5.14 \\
E-04\end{array}$ & $\begin{array}{l}1.17 \\
\mathrm{E}-03\end{array}$ & $\begin{array}{l}2.23 \\
\mathrm{E}-04\end{array}$ & $\begin{array}{l}4.53 \\
E-03\end{array}$ & $\begin{array}{l}8.57 \\
E-03\end{array}$ \\
\hline $\begin{array}{l}\text { Normalization g Ethene } \\
\text {-Equiv. (Process) }\end{array}$ & \multicolumn{3}{|c|}{$3.63 E-02$} & \multicolumn{3}{|c|}{$2.84 \mathrm{E}-03$} & \multicolumn{3}{|c|}{$1.33 \mathrm{E}-02$} \\
\hline $\begin{array}{l}\text { Normalization g Ethene -Equiv. } \\
\text { (Electricity Coal Supply Chain) }\end{array}$ & \multicolumn{9}{|c|}{$5.24 \mathrm{E}-02$} \\
\hline
\end{tabular}

Note: Data in above table rounded off to two decimals.

Table 9. POCP of waste gases in electricity coal supply chain ( $\mathrm{g} / \mathrm{KWh}$ )

\subsubsection{Acidification Potential}

Acidification Potential (AP) is based on the contributions of $\mathrm{SO}_{2}, \mathrm{NO}_{x}, \mathrm{HCl}, \mathrm{NH}_{3}$ and $\mathrm{HF}$ to the potential acid deposition in the form of $\mathrm{H}$ ( (protons). Appendix $\mathrm{A}$ shows that $\mathrm{SO}_{2}, \mathrm{NOx}, \mathrm{HCl}$, $\mathrm{HF}$ and $\mathrm{NH}_{3}$ mainly come from coal mining process and transportation process, and emissions of $\mathrm{HCl}, \mathrm{HF}$ and $\mathrm{NH}_{3}$ relative to emissions of $\mathrm{SO}_{2}$ and $\mathrm{NO}_{x}$ are negligible. AP in the electricity coal supply chain is calculated in Table 10. In the coal life cycle, AP mainly occurs in the coal burning process. So reducing the emissions of $\mathrm{SO}_{2}$ and $\mathrm{NO}_{x}$ in the coal burning process is the main approach to decrease AP in the electricity coal supply chain.

\begin{tabular}{|l|c|c|c|c|c|c|}
\hline & \multicolumn{2}{|c|}{ Mining Process } & Transportation Process & \multicolumn{2}{c|}{ Burning Process } \\
\hline Stressors & $\mathrm{NO}_{x}$ & $\mathrm{SO}_{2}$ & $\mathrm{NO}_{x}$ & $\mathrm{SO}_{2}$ & $\mathrm{NO}_{x}$ & $\mathrm{SO}_{2}$ \\
\hline Amount & $4.01 \mathrm{E}-01$ & $3.67 \mathrm{E}-01$ & $7.98 \mathrm{E}-02$ & $2.64 \mathrm{E}-03$ & $9.54 \mathrm{E}-01$ & $8.20 \mathrm{E}-01$ \\
\hline Normalization $\mathrm{g} \mathrm{SO}_{2}$-Equiv. & $2.81 \mathrm{E}-01$ & $3.67 \mathrm{E}-01$ & $5.59 \mathrm{E}-02$ & $2.64 \mathrm{E}-03$ & $6.68 \mathrm{E}-01$ & $8.20 \mathrm{E}-01$ \\
\hline Normalization $\mathrm{g} \mathrm{SO}_{2}$-Equiv. (Process) & \multicolumn{5}{|c|}{$6.48 \mathrm{E}-01$} & \multicolumn{2}{|c|}{$2.19 \mathrm{E}+00$} & $1.49 \mathrm{E}+00$ \\
\hline $\begin{array}{l}\text { Normalization } \mathrm{g} \mathrm{SO}_{2} \text {-Equiv. } \\
\text { (Electricity Coal Supply Chain) }\end{array}$ & \multicolumn{5}{|l|}{} \\
\hline
\end{tabular}

Note: Data in above table rounded off to two decimals.

Table 10. AP of waste gases in electricity coal supply chain $(\mathrm{g} / \mathrm{KWh})$ 


\subsubsection{Ozone Depletion Potential}

Ozone Depletion Potential (ODP) indicates the potential for emissions of chlorofluorocarbon (CFC) compounds and other halogenated hydrocarbons to deplete the ozone layer. ODP in the electricity coal supply chain is calculated in Table 11 . In the coal life cycle, ODP mainly occurs in the coal burning process. So reducing the emissions of CFC-11, R114, R12 and R22 in the coal burning process is the main approach to decrease ODP in the electricity coal supply chain.

\begin{tabular}{|c|c|c|c|c|c|c|c|c|c|c|c|c|}
\hline \multirow[b]{2}{*}{ Stressors } & \multicolumn{4}{|c|}{ Mining Process } & \multicolumn{4}{|c|}{ Transportation Process } & \multicolumn{4}{|c|}{ Burning Process } \\
\hline & $\mathrm{R} 11$ & $\mathrm{R} 114$ & $\mathrm{R} 12$ & $\mathrm{R} 22$ & $\mathrm{R} 11$ & $\mathrm{R} 114$ & $\mathrm{R} 12$ & $\mathrm{R} 22$ & $\mathrm{R} 11$ & $\mathrm{R} 114$ & $\mathrm{R} 12$ & R22 \\
\hline Amount & $\begin{array}{l}8.27 \\
\mathrm{E}-08\end{array}$ & $\begin{array}{l}8.47 \\
\mathrm{E}-08\end{array}$ & $\begin{array}{l}1.78 \\
\mathrm{E}-08\end{array}$ & $\begin{array}{l}1.94 \\
E-08\end{array}$ & 0 & 0 & 0 & 0 & $\begin{array}{l}4.88 \\
E-07\end{array}$ & $\begin{array}{l}5.00 \\
E-07\end{array}$ & $\begin{array}{l}1.05 \\
E-07\end{array}$ & $\begin{array}{l}1.15 \\
\mathrm{E}-07\end{array}$ \\
\hline Normalization g R11-Equiv. & $\begin{array}{l}8.27 \\
\mathrm{E}-08\end{array}$ & $\begin{array}{l}7.20 \\
\mathrm{E}-08\end{array}$ & $\begin{array}{l}1.46 \\
E-08\end{array}$ & $\begin{array}{l}6.60 \\
E-10\end{array}$ & 0 & 0 & 0 & 0 & $\begin{array}{l}4.88 \\
E-07\end{array}$ & $\begin{array}{l}4.25 \\
E-07\end{array}$ & $\begin{array}{l}8.61 \\
E-08\end{array}$ & $\begin{array}{l}3.91 \\
\mathrm{E}-09\end{array}$ \\
\hline $\begin{array}{l}\text { Normalization g R11-Equiv. } \\
\text { (Process) }\end{array}$ & \multicolumn{4}{|c|}{$1.70 \mathrm{E}-07$} & \multicolumn{4}{|c|}{0} & \multicolumn{4}{|c|}{$1.00 \mathrm{E}-06$} \\
\hline $\begin{array}{l}\text { Normalization g R11-Equiv. } \\
\text { (Electricity Coal Supply Chain) }\end{array}$ & \multicolumn{12}{|c|}{$1.17 \mathrm{E}-06$} \\
\hline
\end{tabular}

Note: Data in above table rounded off to two decimals.

Table 11. ODP of waste gases in electricity coal supply chain $(\mathrm{g} / \mathrm{KWh})$

Based on the above analysis, GWP, EP, POCP, AP and ODP in the coal mining process, coal transportation process and coal burning process are shown in Table 12.

\begin{tabular}{|l|c|c|c|c|c|}
\hline Classification & $\begin{array}{c}\text { Mining } \\
\text { Process }\end{array}$ & $\begin{array}{c}\text { Transportation } \\
\text { Process }\end{array}$ & $\begin{array}{c}\text { Burning } \\
\text { Process }\end{array}$ & $\begin{array}{c}\text { Electricity Coal } \\
\text { Supply Chain }\end{array}$ & Unit \\
\hline GWP & $1.40 \mathrm{E}-01$ & $1.69 \mathrm{E}-02$ & $9.23 \mathrm{E}-01$ & $1.08 \mathrm{E}+00$ & $\mathrm{~kg} \mathrm{CO}_{2}$-Equiv. \\
\hline EP & $5.23 \mathrm{E}-05$ & $1.04 \mathrm{E}-05$ & $1.26 \mathrm{E}-04$ & $1.89 \mathrm{E}-04$ & $\mathrm{~kg} \mathrm{PO}_{4}{ }^{3}$-Equiv. \\
\hline POCP & $3.63 \mathrm{E}-05$ & $2.84 \mathrm{E}-06$ & $1.33 \mathrm{E}-05$ & $5.24 \mathrm{E}-05$ & $\mathrm{~kg} \mathrm{C}_{2} \mathrm{H}_{4}$-Equiv. \\
\hline AP & $6.57 \mathrm{E}-04$ & $5.85 \mathrm{E}-05$ & $1.51 \mathrm{E}-03$ & $2.22 \mathrm{E}-03$ & $\mathrm{~kg} \mathrm{SO}_{2}$-Equiv. \\
\hline ODP & $1.70 \mathrm{E}-10$ & $0.00 \mathrm{E}+00$ & $1.00 \mathrm{E}-09$ & $1.17 \mathrm{E}-09$ & $\mathrm{~kg} \mathrm{R} 11$-Equiv. \\
\hline
\end{tabular}

Table 12. Impact assessment of each process in electricity coal supply chain

\subsubsection{Normalization}

A normalization step is performed to provide the relative size of each environmental impact. Each of the total characterized scores is benchmarked against the known total effect (usually based on the country's average) for their respective "class". Currently there are many life cycle impact assessment (LCIA) methods such as CML 2001, Eco-Indicator 95 (Goedkoop, Demmers \& Collignon, 1995), Eco-Indicator 99 (Goedkoop \& Spriensma, 2001), EDIP 1997 (Wenzel, 
Hauschild, Alting \& editors, 1997), EDIP 2003 (Dreyer, Niemann \& Hauschild, 2003), IMPACT $2002+$ (Jolliet, Margni, Charles, Humbert, Payet, Rebitzer et al., 2003), Ecological Scarcity (UBP Method) (Frischknecht, Steiner \& Jungbluth, 2009) and so on. However, the shortcomings of these methods are that most indicators, normalization factors and weighting factors are based on the data of Netherlands, Denmark, and the European Union. Because these normalization factor and weighting factors depend on the actual conditions of a particular country or region, they cannot be used to process the data of the Chinese electricity coal supply chain. Thus, this paper uses Chinese normalization factors and weighting factors given by the Environment Research Center in Chinese Academy of Science and Technical University of Denmark (Yang, Cheng \& Wang, 2002). Table 13 illustrates that in the electricity coal supply chain, the biggest environmental impact of waste gas emissions is GWP, followed by EP, POCP, $A P$ and ODP.

\subsubsection{Final weighted scores}

It is assumed that the relative importance of various impacts is the same. However, in fact, the relative importance of various impacts is different, which on the one hand depends on the characteristics of the environment itself, while on the other hand this reflects the current understanding of human society and its degree of concern. In the final stage, the normalized scores are multiplied by a weighting factor representing the relative importance of the total environmental impact. The environmental impacts of GWP, EP, POCP, AP and ODP after weighting are shown in Table 13. It is seen that the coal burning process has the biggest environmental impact, followed by the coal mining process and the coal transportation process.

Table 13 presents that the biggest environmental impact in the electricity coal supply chain is GWP, then followed by EP, AP, POCP and ODP. The global environmental burden of the electricity coal supply chain is $1.03 \mathrm{E}-04 \mathrm{man} \cdot \mathrm{a}$, and the regional environmental burden of the electricity coal supply chain is $1.58 \mathrm{E}-04 \mathrm{man} \cdot \mathrm{a}$., so the regional impact is greater than the global impact. The environmental burden of the electricity coal supply chain is $2.61 \mathrm{E}-04$ man.a. 


\begin{tabular}{|c|c|c|c|c|c|c|c|c|}
\hline \multicolumn{2}{|c|}{ Classification } & Step & $\begin{array}{l}\text { Mining } \\
\text { process }\end{array}$ & $\begin{array}{c}\text { Transportation } \\
\text { process }\end{array}$ & $\begin{array}{l}\text { Burning } \\
\text { process }\end{array}$ & $\begin{array}{l}\text { Electricity coal } \\
\text { supply chain }\end{array}$ & Category & $\begin{array}{l}\text { Environmental } \\
\text { burden }\end{array}$ \\
\hline \multirow{4}{*}{ Global } & \multirow{2}{*}{ GWP } & Normalization & $1.61 \mathrm{E}-05$ & $1.94 \mathrm{E}-06$ & $1.06 \mathrm{E}-04$ & $1.24 \mathrm{E}-04$ & \multirow{4}{*}{$1.03 \mathrm{E}-04$} & \multirow{11}{*}{$2.61 \mathrm{E}-04$} \\
\hline & & Weighting & $1.34 \mathrm{E}-05$ & $1.61 \mathrm{E}-06$ & $8.81 \mathrm{E}-05$ & $1.03 \mathrm{E}-04$ & & \\
\hline & \multirow{2}{*}{ ODP } & Normalization & $8.50 E-10$ & $0.00 E+00$ & 5.00E-09 & 5.85E-09 & & \\
\hline & & Weighting & $2.30 \mathrm{E}-09$ & $0.00 E+00$ & $1.35 \mathrm{E}-08$ & $1.58 \mathrm{E}-08$ & & \\
\hline \multirow{6}{*}{ Regional } & \multirow{2}{*}{ AP } & Normalization & $1.88 \mathrm{E}-05$ & $1.67 \mathrm{E}-06$ & $4.31 \mathrm{E}-05$ & $6.34 \mathrm{E}-05$ & \multirow{7}{*}{$1.58 \mathrm{E}-04$} & \\
\hline & & Weighting & $1.37 \mathrm{E}-05$ & $1.22 \mathrm{E}-06$ & $3.15 \mathrm{E}-05$ & $4.63 \mathrm{E}-05$ & & \\
\hline & \multirow{2}{*}{$\mathrm{EP}$} & Normalization & $2.84 \mathrm{E}-05$ & 5.65E-06 & $6.85 \mathrm{E}-05$ & $1.03 \mathrm{E}-04$ & & \\
\hline & & Weighting & $2.07 E-05$ & $4.13 E-06$ & $5.00 \mathrm{E}-05$ & $7.50 \mathrm{E}-05$ & & \\
\hline & \multirow{2}{*}{ POCP } & Normalization & $4.78 \mathrm{E}-05$ & $3.74 \mathrm{E}-06$ & $1.75 \mathrm{E}-05$ & $6.89 \mathrm{E}-05$ & & \\
\hline & & Weighting & $2.53 E-05$ & $1.98 \mathrm{E}-06$ & $9.28 \mathrm{E}-06$ & $3.65 E-05$ & & \\
\hline \multicolumn{2}{|l|}{ Sum } & Weighting & $7.31 \mathrm{E}-05$ & $8.94 \mathrm{E}-06$ & $1.79 E-04$ & $2.61 \mathrm{E}-04$ & & \\
\hline
\end{tabular}

Table 13. Impact assessment in electricity coal supply chain (Unit: man·a)

\section{Sensitivity analysis}

A sensitivity analysis was conducted to determine the parameters that had the largest effect on the results and to determine the impact of estimated data as well as variations in data on the conclusions. One variable may affect several factors and thus several process steps, or it may affect only one process in the overall life cycle assessment. For instance, changing the coal-burning efficiency can affect the amount of coal required at the plant, which in turn affects the coal mining and transportation requirements. However, varying the transportation distance affects only the emissions associated with the coal transportation process. These effects were taken into account automatically in the LCA model. The base case assumed transportation to the average user (QLQP) by truck. The following are abbreviations used in the different sensitivity analyses: A means base case; $\mathrm{B}$ means $\mathrm{CH}_{4}$ utilization ratio is $30 \%$; $\mathrm{C}$ means nearest user; $D$ means farthest user; $E$ means increase coal-burning efficiency by 5 points; $F$ means decrease coal-burning efficiency by 5 points.

\subsection{Coal mining process - utilization ratio of $\mathrm{CH}_{4}$ sensitivity analysis}

$\mathrm{CH}_{4}$ emissions in the electricity coal supply chain is mainly caused by the emissions of CBM in the coal mining process, which accounts for $94 \%$ of the total $\mathrm{CH}_{4}$ emissions in the electricity coal supply chain. So the reduction of $\mathrm{CH}_{4}$ emissions mainly focuses on the coal mining process, and the utilization of $\mathrm{CH}_{4}$ as an alternative mode of power generation. At present, the utilization of mine gas is mainly based on civil and industrial use; this percentage has already reached $80 \%$ (Zhuo, Lin \& Wang, 2008). The gas chemical industry also has wide market prospects, and gas power generation is a leading direction of development. Methane-power generation (heat supply) is used in many large industries. Methane power generation is a 
mature technology, with the main technologies being gas turbine power generation, steam turbine power generation, gas-fired generator power generation, combined cycle system power generation and CHER power generation.

The coal seam in JZCM has low air permeability and the coal bed is soft, so recovery and utilization of CBM is quite difficult. In addition, without data about power consumption of $\mathrm{CH}_{4}$ recovery equipment, the waste gas emissions from the equipment is ignored. Thus, this paper considers the environmental impacts caused by waste gas emissions in the electricity coal supply chain based on the assumption that the utilization ratio of $\mathrm{CH}_{4}$ can reach $30 \%$. The results are shown in Table 14 and a comparative analysis of impact assessment is made in Table 15.

\begin{tabular}{|c|c|c|c|c|c|}
\hline Classification & Environmental burden & Normalization factor & Normalization & $\begin{array}{l}\text { Weighting } \\
\text { factor }\end{array}$ & Weighting \\
\hline GWP & $\begin{array}{c}1.05 \mathrm{E}+00 \mathrm{~kg} \\
\mathrm{CO}_{2} \text {-Equiv. }\end{array}$ & $8700 \mathrm{Kg} \mathrm{CO} 2$ eq./(man·a) & $\begin{array}{c}1.21 \mathrm{E}-04 \\
\operatorname{man} \cdot \mathrm{a}\end{array}$ & 0.83 & $\begin{array}{c}1.00 \mathrm{E}-04 \\
\mathrm{man} \cdot \mathrm{a}\end{array}$ \\
\hline EP & $\begin{array}{c}1.89 \mathrm{E}-04 \mathrm{~kg} \\
\mathrm{PO}_{4}{ }^{3} \text {-Equiv. }\end{array}$ & $1.84 \mathrm{Kg} \mathrm{PO}_{4}{ }^{3}-$ eq./(man.a $)$ & $\begin{array}{c}1.03 \mathrm{E}-04 \\
\mathrm{man} \cdot \mathrm{a}\end{array}$ & 0.73 & $\begin{array}{c}7.52 \mathrm{E}-05 \\
\mathrm{man} \cdot \mathrm{a}\end{array}$ \\
\hline POCP & $\begin{array}{c}4.85 \mathrm{E}-05 \mathrm{~kg} \\
\mathrm{C}_{2} \mathrm{H}_{4} \text {-Equiv. }\end{array}$ & $0.76 \mathrm{Kg} \mathrm{C}_{2} \mathrm{H}_{4}$ eq./(man·a) & $\begin{array}{c}6.38 \mathrm{E}-05 \\
\mathrm{man} \cdot \mathrm{a}\end{array}$ & 0.53 & $\begin{array}{c}3.38 \mathrm{E}-05 \\
\mathrm{man} \cdot \mathrm{a}\end{array}$ \\
\hline AP & $\begin{array}{c}2.22 \mathrm{E}-03 \mathrm{~kg} \\
\mathrm{SO}_{2} \text {-Equiv. }\end{array}$ & $35 \mathrm{Kg} \mathrm{SO}_{2}$ eq./(man·a) & $\begin{array}{c}6.34 \mathrm{E}-05 \\
\mathrm{man} \cdot \mathrm{a}\end{array}$ & 0.73 & $\begin{array}{c}4.63 \mathrm{E}-05 \\
\mathrm{man} \cdot \mathrm{a}\end{array}$ \\
\hline ODP & $\begin{array}{c}1.17 \mathrm{E}-09 \mathrm{~kg} \\
\text { R11-Equiv. }\end{array}$ & $0.2 \mathrm{Kg} \mathrm{R} 11$ eq./(man.a) & $\begin{array}{c}5.85 \mathrm{E}-09 \\
\mathrm{man} \cdot \mathrm{a}\end{array}$ & 2.7 & $\begin{array}{c}1.58 \mathrm{E}-08 \\
\mathrm{man} \cdot \mathrm{a}\end{array}$ \\
\hline
\end{tabular}

Table 14 . Normalization and weighting analysis (utilization rate of $\mathrm{CH} 4$ is $30 \%$ )

\begin{tabular}{|c|c|c|c|c|c|c|c|c|c|c|}
\hline \multirow{2}{*}{\multicolumn{2}{|c|}{ Classification }} & \multicolumn{3}{|c|}{ Final weighted scores } & \multicolumn{3}{|c|}{ Category } & \multicolumn{3}{|c|}{ Environmental burden } \\
\hline & & A & B & $\begin{array}{l}\text { Changing } \\
\text { rate }\end{array}$ & A & B & $\begin{array}{l}\text { Changing } \\
\text { rate }\end{array}$ & A & B & $\begin{array}{l}\text { Changing } \\
\text { rate }\end{array}$ \\
\hline \multirow{2}{*}{ Global } & GWP & $1.03 E-04$ & $1.00 \mathrm{E}-04$ & $-2.91 \%$ & \multirow{2}{*}{$\begin{array}{l}1.03 \\
E-04\end{array}$} & \multirow{2}{*}{$\begin{array}{l}1.00 \\
\text { E-04 }\end{array}$} & \multirow{2}{*}{$-2.91 \%$} & \multirow{5}{*}{$\begin{array}{l}2.61 \\
E-04\end{array}$} & \multirow{5}{*}{$\begin{array}{l}2.55 \\
E-04\end{array}$} & \multirow{5}{*}{$-2.30 \%$} \\
\hline & ODP & $1.58 \mathrm{E}-08$ & $1.58 \mathrm{E}-08$ & $0.00 \%$ & & & & & & \\
\hline \multirow{3}{*}{ Regional } & AP & $4.63 E-05$ & 4.63E-05 & $0.00 \%$ & \multirow{3}{*}{$\begin{array}{l}1.58 \\
E-04\end{array}$} & \multirow{3}{*}{$\begin{array}{l}1.55 \\
E-04\end{array}$} & \multirow{3}{*}{$-1.90 \%$} & & & \\
\hline & EP & $7.52 \mathrm{E}-05$ & $7.52 \mathrm{E}-05$ & $0.00 \%$ & & & & & & \\
\hline & POCP & $3.65 \mathrm{E}-05$ & $3.38 \mathrm{E}-05$ & $-7.40 \%$ & & & & & & \\
\hline
\end{tabular}

Table 15. Comparative analysis of impact assessment in electricity coal supply chain (Unit: man·a)

Under the assumption that the utilization ratio of $\mathrm{CH}_{4}$ is $30 \%$ in the coal mining process, Table 15 gives the global environmental burden, regional environmental burden and total environmental burden of waste gas emissions in the electricity coal supply chain change as $2.91 \%, 1.9 \%$ and $2.3 \%$, respectively. So the environmental burden caused by waste gases emissions is not sensitive to the change of $\mathrm{CH}_{4}$ in the coal mining process and utilization of $\mathrm{CH}_{4}$ is not an effective method to reduce the environmental burden in the electricity coal supply chain. 


\subsection{Coal transportation process - transportation distance sensitivity analysis}

This section analyzes sensitivity of transportation distance and studies the environmental impact of transportation distance on waste gas emissions in the electricity coal supply chain. According to the investigation of JZCM, the fastest user is Yangzhou power plant, and the nearest user is JZ plant, mine mouth power plant. Detailed data are shown in Table 16.

\begin{tabular}{|l|l|l|l|}
\hline \multicolumn{1}{|c|}{ Scenario } & \multicolumn{1}{|c|}{ Vehicles } & \multicolumn{1}{c|}{ Path } & \multicolumn{1}{c|}{ Distance } \\
\hline Base case & Truck & Jiangzhuang coal mine--->Shiliquan power plant & Highway 93Km \\
\hline Nearest user & Truck & JZ power plant & Highway $2 \mathrm{Km}$ \\
\hline Farthest user & $\begin{array}{l}\text { Barge and } \\
\text { truck }\end{array}$ & $\begin{array}{l}\text { Jiangzhuang coal mine---> Zaozhuang port---> Jinghang canal } \\
--->\text { Yangzhou port--->Yangzhou power plant }\end{array}$ & $\begin{array}{l}\text { Highway 89Km, } \\
\text { Waterway 427Km }\end{array}$ \\
\hline
\end{tabular}

Table 16. Comparison of three scenarios

Table 17 gives the change of input index (standard coal, diesel, electricity consumption and non-coal energy) and Table 18 presents the change of output index (GWP, EP, POCP, AP and ODP), in order to assess the environmental impact of three different of transportation distances. And it shows that change of transportation distance has a great influence on diesel and non-coal energy.

\begin{tabular}{|l|l|l|l|l|l|}
\multicolumn{1}{|c|}{ Input index } & \multicolumn{1}{c|}{ Quality } & \multicolumn{1}{c|}{ Unit } & \multicolumn{1}{c|}{ C A } & \multicolumn{1}{c|}{ D } \\
\hline Standard coal & Mass & $\mathrm{g}$ & $-0.01 \%$ & 438.171 & $0.03 \%$ \\
\hline Diesel & Mass & $\mathrm{g}$ & $-48.96 \%$ & 12.1 & $243.31 \%$ \\
\hline Electricity consumption & Energy (gross calorific value) & MJ & $-2.41 \%$ & 0.0325 & $7.01 \%$ \\
\hline Non-coal energy & Energy (gross calorific value) & MJ & $-33.62 \%$ & 0.7239 & $112.97 \%$ \\
\hline
\end{tabular}

Table 17. Impact of electricity coal supply chain on transportation distance (Input index)

Table 18 illustrates POCP is most sensitive to fluctuations of transportation distance compared with GWP, ODP, AP, EP, because large amounts of $\mathrm{CO}$ are released in the coal transportation process. Therefore an oxidation catalyst on the vehicles is recommended to oxidize the carbon monoxide into carbon dioxide. 


\begin{tabular}{|c|c|c|c|c|c|c|c|c|c|c|}
\hline \multirow{2}{*}{\multicolumn{2}{|c|}{ Classification }} & \multicolumn{3}{|c|}{ Final weighted scores } & \multicolumn{3}{|c|}{ Category } & \multicolumn{3}{|c|}{ Environmental burden } \\
\hline & & $\mathbf{A}$ & C & Changing rate & $\mathbf{A}$ & C & Changing rate & A & C & Changing rate \\
\hline \multirow{2}{*}{ Global } & GWP & $1.03 E-04$ & $1.01 \mathrm{E}-04$ & $-1.85 \%$ & \multirow{2}{*}{$\begin{array}{l}1.03 \\
E-04\end{array}$} & \multirow{2}{*}{$\begin{array}{l}1.01 \\
E-04\end{array}$} & \multirow{2}{*}{$-1.83 \%$} & \multirow{5}{*}{$\begin{array}{l}2.61 \\
E-04\end{array}$} & \multirow{5}{*}{$\begin{array}{l}2.51 \\
E-04\end{array}$} & \multirow{5}{*}{$-3.70 \%$} \\
\hline & ODP & $1.58 \mathrm{E}-08$ & $1.58 \mathrm{E}-08$ & $0.00 \%$ & & & & & & \\
\hline \multirow{3}{*}{ Regional } & AP & 4.63E-05 & $4.54 \mathrm{E}-05$ & $-2.02 \%$ & \multirow{3}{*}{$\begin{array}{l}1.58 \\
E-04\end{array}$} & \multirow{3}{*}{$\begin{array}{l}1.50 \\
E-04\end{array}$} & \multirow{3}{*}{$-4.92 \%$} & & & \\
\hline & EP & $7.52 \mathrm{E}-05$ & $7.52 \mathrm{E}-05$ & $-0.01 \%$ & & & & & & \\
\hline & POCP & $3.65 E-05$ & 2.97E-05 & $-18.71 \%$ & & & & & & \\
\hline \multirow{2}{*}{\multicolumn{2}{|c|}{ Classification }} & \multicolumn{3}{|c|}{ Final weighted scores } & \multicolumn{3}{|c|}{ Category } & \multicolumn{3}{|c|}{ Environmental burden } \\
\hline & & $\mathbf{A}$ & D & Changing rate & $\mathbf{A}$ & D & Changing rate & A & D & Changing rate \\
\hline \multirow{2}{*}{ Global } & GWP & $1.03 E-04$ & $1.09 E-04$ & $6.31 \%$ & \multirow{2}{*}{$\begin{array}{l}1.03 \\
\text { E-04 }\end{array}$} & \multirow{2}{*}{$\begin{array}{l}1.10 \\
E-04\end{array}$} & \multirow{2}{*}{$6.33 \%$} & \multirow{5}{*}{$\begin{array}{l}2.61 \\
E-04\end{array}$} & \multirow{5}{*}{$\begin{array}{l}2.84 \\
E-04\end{array}$} & \multirow{5}{*}{$8.89 \%$} \\
\hline & ODP & $1.58 \mathrm{E}-08$ & $1.58 \mathrm{E}-08$ & $0.00 \%$ & & & & & & \\
\hline \multirow{3}{*}{ Regional } & AP & 4.63E-05 & $4.88 \mathrm{E}-05$ & $5.41 \%$ & \multirow{3}{*}{$\begin{array}{l}1.58 \\
E-04\end{array}$} & \multirow{3}{*}{$\begin{array}{l}1.75 \\
E-04\end{array}$} & \multirow{3}{*}{$10.55 \%$} & & & \\
\hline & EP & $7.52 E-05$ & $7.52 E-05$ & $0.03 \%$ & & & & & & \\
\hline & POCP & $3.65 E-05$ & $5.06 \mathrm{E}-05$ & $38.76 \%$ & & & & & & \\
\hline
\end{tabular}

Table 18. Impact of electricity coal supply chain on transportation distance (Output index)

\subsection{Coal burning process - coal-burning efficiency sensitivity analysis}

Both a decrease and an increase in the coal-burning efficiency were examined. The base case efficiency for the average is $37 \%$. The coal-burning efficiency is changed by plus or minus five percentage points for each system, i.e., $32 \%$ and $42 \%$ for the Average system. Changing the coal-burning efficiency had a large effect on the energy efficiency and energy ratios defined in Table 19.

\begin{tabular}{|l|l|c|c|c|c|}
\multicolumn{1}{|c|}{ Input index } & \multicolumn{1}{c|}{ Quality } & Unit & E & A & F \\
\hline Standard coal & Mass & $\mathrm{g}$ & $-12.91 \%$ & 438.171 & $17.43 \%$ \\
\hline Diesel & Mass & $\mathrm{g}$ & $-12.91 \%$ & 12.1 & $17.43 \%$ \\
\hline Electricity consumption & Energy (gross calorific value) & MJ & $-12.91 \%$ & 0.0325 & $17.43 \%$ \\
\hline Non-coal energy & Energy (gross calorific value) & MJ & $-12.91 \%$ & 0.7239 & $17.43 \%$ \\
\hline
\end{tabular}

Table 19. Impact of electricity coal supply chain on coal boiler efficiency (Input index)

Table 20 shows the base case as well as the results for increasing and decreasing the coalburning efficiency. So improving the coal-burning efficiency of a coal-fired power plant in the electricity coal supply chain is the most effective way to reduce the environmental burden of waste gas emissions. 


\begin{tabular}{|c|c|c|c|c|c|c|c|c|c|c|}
\hline \multirow{2}{*}{\multicolumn{2}{|c|}{ Classification }} & \multicolumn{3}{|c|}{ Final weighted scores } & \multicolumn{3}{|c|}{ Category } & \multicolumn{3}{|c|}{ Environmental burden } \\
\hline & & Base case & $\mathbf{E}$ & $\begin{array}{l}\text { Changing } \\
\text { rate }\end{array}$ & $\begin{array}{l}\text { Base } \\
\text { case }\end{array}$ & $\mathbf{E}$ & $\begin{array}{l}\text { Changing } \\
\text { rate }\end{array}$ & $\begin{array}{l}\text { Base } \\
\text { case }\end{array}$ & $E$ & $\begin{array}{c}\text { Changing } \\
\text { rate }\end{array}$ \\
\hline \multirow{2}{*}{ Global } & GWP & $1.03 E-04$ & 8.97E-05 & $-12.91 \%$ & \multirow{2}{*}{$\begin{array}{l}1.03 \\
E-04\end{array}$} & \multirow{2}{*}{$\begin{array}{l}8.97 \\
E-05\end{array}$} & \multirow{2}{*}{$-12.90 \%$} & \multirow{5}{*}{$\begin{array}{l}2.61 \\
E-04\end{array}$} & \multirow{5}{*}{$\begin{array}{l}2.27 \\
E-04\end{array}$} & \multirow{5}{*}{$-12.90 \%$} \\
\hline & ODP & $1.58 E-08$ & $1.38 \mathrm{E}-08$ & $-12.91 \%$ & & & & & & \\
\hline \multirow{3}{*}{ Regional } & AP & 4.63E-05 & $4.03 E-05$ & $-12.91 \%$ & \multirow{3}{*}{$\begin{array}{l}1.58 \\
E-04\end{array}$} & \multirow{3}{*}{$\begin{array}{l}1.38 \\
E-04\end{array}$} & \multirow{3}{*}{$-12.91 \%$} & & & \\
\hline & EP & $7.52 \mathrm{E}-05$ & $6.55 E-05$ & $-12.91 \%$ & & & & & & \\
\hline & POCP & 3.65E-05 & $3.18 E-05$ & $-12.91 \%$ & & & & & & \\
\hline \multirow{2}{*}{\multicolumn{2}{|c|}{ Classification }} & \multicolumn{3}{|c|}{ Final weighted scores } & \multicolumn{3}{|c|}{ Category } & \multicolumn{3}{|c|}{ Environmental burden } \\
\hline & & Base case & $\mathbf{F}$ & $\begin{array}{l}\text { Changing } \\
\text { rate }\end{array}$ & $\begin{array}{l}\text { Base } \\
\text { case }\end{array}$ & $\mathbf{F}$ & $\begin{array}{l}\text { Changing } \\
\text { rate }\end{array}$ & $\begin{array}{l}\text { Base } \\
\text { case }\end{array}$ & $\mathbf{F}$ & $\begin{array}{c}\text { Changing } \\
\text { rate }\end{array}$ \\
\hline \multirow{2}{*}{ Global } & GWP & 1.03E-04 & $1.21 \mathrm{E}-04$ & $17.43 \%$ & \multirow{2}{*}{$\begin{array}{l}1.03 \\
E-04\end{array}$} & \multirow{2}{*}{$\begin{array}{l}1.21 \\
E-04\end{array}$} & \multirow{2}{*}{$17.45 \%$} & \multirow{5}{*}{$\begin{array}{l}2.61 \\
E-04\end{array}$} & \multirow{5}{*}{$\begin{array}{l}3.07 \\
E-04\end{array}$} & \multirow{5}{*}{$17.44 \%$} \\
\hline & ODP & $1.58 \mathrm{E}-08$ & $1.86 \mathrm{E}-08$ & $17.43 \%$ & & & & & & \\
\hline \multirow{3}{*}{ Regional } & AP & 4.63E-05 & $5.44 \mathrm{E}-05$ & $17.43 \%$ & \multirow{3}{*}{$\begin{array}{l}1.58 \\
E-04\end{array}$} & \multirow{3}{*}{$\begin{array}{l}1.86 \\
E-04\end{array}$} & \multirow{3}{*}{$17.43 \%$} & & & \\
\hline & EP & $7.52 \mathrm{E}-05$ & 8.83E-05 & $17.43 \%$ & & & & & & \\
\hline & POCP & $3.65 E-05$ & $4.29 E-05$ & $17.43 \%$ & & & & & & \\
\hline
\end{tabular}

Table 20. Impact of electricity coal supply chain on coal boiler efficiency (Output index)

\section{Conclusion}

LCA results help to pinpoint several tangible strategies to decrease the environmental impact in the coal life cycle, from coal mine to coal-fired power plant. The results show that the environmental burden of the coal burning process is greatest, followed by the coal mining process, and finally the coal transportation process. In the electricity coal supply chain, the biggest environmental impact of waste gas emissions is GWP, followed by EP, AP, POCP and ODP, and the regional impact is greater than the global impact. Improving the coal-burning efficiency of a coal-fired power plant is the most effective way to reduce the environmental burden of waste gas emissions in the electricity coal supply chain.

While there are certain limitations in the LCA supply chain case study in its current "cradle-togate" approach, in future research a full LCA study will incorporate a "cradle-to-grave" scheme including recycling, re-use and/or various disposal methods. And a cost factor will be integrated with LCA methods.

\section{Acknowledgement}

The research supported by The Key National Natural Science Foundation of China "Research of logistics resource integration and optimization" (Grant No. 71132008), China Scholarship Council (201207090034), and the Fundamental Research Funds for the Central Universities (2012YJS034). We gratefully acknowledge the assistance of Yanqiang Yin, which had offered a survey in Jiangzhuang Coal Mine of Zaozhuang. We also thank Douglas Helman and Zhixiao Gu which has assisted in using $\mathrm{GaBi} 4$ Education software. 
The authors are grateful to the anonymous referees for a careful checking and helpful comments that improved this paper.

\section{References}

Bates, J. (1995). Full life cycle atmospheric emissions and global warming impacts from UK electricity generation. London.

Björk, A., Erlandsson, M., Häkli, J., Jaakkola, K., Nilsson, A., Nummila, K., et al. (2011). Monitoring environmental performance of the forestry supply chain using RFID. Computers in Industry, 62(8), 830-841. http://dx.doi.org/10.1016/j.compind.2011.08.001

Clean Production Standard in Coal Washing and Processing Industry. (2010). HJ 446-2008. China Department of the environment.

CSY. (2013). China Statisitcal Yearbook 2012. Beijing.

Dreyer, L.C., Niemann, A.L., \& Hauschild, M.Z. (2003). Comparison of three different LCIA methods: EDIP97, CML2001 and Eco-indicator 99. The international journal of life cycle assessment, 8(4), 191-200. http://dx.doi.org/10.1007/BF02978471

Frischknecht, R., Steiner, R., \& Jungbluth, N. (2009). The Ecological Scarcity Method-Eco-Factors 2006-A method for impact assessment in LCA (Methode der ökologischen Knappheit-Ökofaktoren 2006-Methode für die Wirkungsabschätzung in Ökobilanzen).

Goedkoop, M., Demmers, M., \& Collignon, M. (1995). The eco-indicator 95. PRé Consultants Amersfoort (NL).

Goedkoop, M., \& Spriensma, R. (2001). The eco-indicator99: A damage oriented method for life cycle impact assessment: Methodology report.

Hondo, H. (2005). Life cycle GHG emission analysis of power generation systems: Japanese case. Energy, 30(11), 2042-2056. http://dx.doi.org/10.1016/j.energy.2004.07.020

International Energy Agency, IEA (2010). Electricity Information 2010. In OECO (Ed.). Paris.

Jolliet, O., Margni, M., Charles, R., Humbert, S., Payet, J., Rebitzer, G., et al. (2003). IMPACT 2002+: A new life cycle impact assessment methodology. The international journal of life cycle assessment, 8(6), 324-330. http://dx.doi.org/10.1007/BF02978505

Kannan, R., Leong, K., Osman, R., \& Ho, H. (2007). Life cycle energy, emissions and cost inventory of power generation technologies in Singapore. Renewable and Sustainable Energy Reviews, 11(4), 702-715. http://dx.doi.org/10.1016/j.rser.2005.05.004 
Korre, A., Nie, Z., \& Durucan, S. (2012). Life Cycle Assessment of the natural gas supply chain and power generation options with $\mathrm{CO} 2$ capture and storage: Assessment of Qatar natural gas production, LNG transport and power generation in the UK. Sustainable Technologies, Systems \& Policies(CCS Workshop), 11.

Lave, L.B., \& Freeburg, L.C. (1973). Health effects of electricity generation from coal, oil, and nuclear fuel. Nuclear safety, 14(5), 409-428.

Li, R., \& Leung, G.C.K. (2012). Coal consumption and economic growth in China. Energy policy, 40(0), 438-443. http://dx.doi.org/10.1016/j.enpol.2011.10.034

Liang, X., Wang, Z., Zhou, Z., Huang, Z., Zhou, J., \& Cen, K. (2012). Up-to-date life cycle assessment and comparison study of clean coal power generation technologies in China. Journal of cleaner production, 39(0), 24-31. http://dx.doi.org/10.1016/j.jclepro.2012.08.003

Liu, Z., \& Zhao, Q. (2011). Research on the Scale-Planning Model for the Coal Logistics Center Based on Coal Logistics Network Planning. Journal of System and Management Sciences, 1(1), 59-69.

Lu, Z., Streets, D., Zhang, Q., Wang, S., Carmichael, G., Cheng, Y., et al. (2010). Sulfur dioxide emissions in China and sulfur trends in East Asia since 2000. Atmospheric Chemistry and Physics, 10(13), 6311-6331. http://dx.doi.org/10.5194/acp-10-6311-2010

Mann, M., \& Spath, P. (2001). A life cycle assessment of biomass cofiring in a coal-fired power plant. Clean Products and Processes, 3(2), 81-91. http://dx.doi.org/10.1007/s100980100109

Miao, Y.X. (2009). Exploration and Analysis of 5,000,000 t/a coal washing technology. Hebei Chemical Engineering and Industry, 32(6), 45-47(In Chinese).

Pacca, S., \& Horvath, A. (2002). Greenhouse gas emissions from building and operating electric power plants in the Upper Colorado River Basin. Environmental Science \& Technology, 36(14), 3194-3200. http://dx.doi.org/10.1021/es0155884

Pan, B., \& Mu, D. (2011). Research on CDM projects in electricity coal supply chain. Paper presented at the International Conference on Information, Services and Management Engineering (ISME2011).

PE Intentional. (2011). www.gabi-software.com/america/index/.

Qiu, Z. (2013). On the analysis of building a public information platform based on e-Commerce for coal logistics. Journal of Industrial Engineering and Management, 6(4), 986-995. http://dx.doi.org/10.3926/jiem.746 
Restrepo, Á., Miyake, R., Kleveston, F., \& Bazzo, E. (2012). Exergetic and environmental analysis of a pulverized coal power plant. Energy, 45(1), 195-202.

http://dx.doi.org/10.1016/j.energy.2012.01.080

Uchiyama, Y. (1996). Life cycle analysis of electricity generation and supply systems. A paper in the technical document: IAEA-SM-338/33, 279-291.

Wenzel, H., Hauschild, M., Alting, L., \& editors. (1997). Environmental assessment of products. Vol. 1. London, UK: Chapman \& Hall.

Yan, L.H. (2006). Japanese post-war energy security strategy and implications for China. Beijing, University of International Business and Economics (In Chinese).

Yang, J.X., Cheng, X., \& Wang, R.S. (2002). Methodology and application of life cycle assessment. Beijing: China Meteorological Press (In Chinese).

You, F., Tao, L., Graziano, D.J., \& Snyder, S.W. (2012). Optimal design of sustainable cellulosic biofuel supply chains: Multiobjective optimization coupled with life cycle assessment and input-output analysis. AIChE Journal, 58(4), 1157-1180. http://dx.doi.org/10.1002/aic.12637

Zhao, Y., Wang, S., Nielsen, C. P., Li, X., \& Hao, J. (2010). Establishment of a database of emission factors for atmospheric pollutants from Chinese coal-fired power plants. Atmospheric Environment, 44(12), 1515-1523. http://dx.doi.org/10.1016/j.atmosenv.2010.01.017

Zhuo, C., Lin, B. Q., \& Wang, L. (2008). CBM utilization and problem of underground coal mine in China. Natural gas industry, 28(7), 23-26 (In Chinese). 


\section{Appendix A}

Waste gases emissions in electricity coal supply chain $(\mathrm{g} / \mathrm{KWh})$

\begin{tabular}{|c|c|c|c|c|c|}
\hline \multicolumn{2}{|r|}{ Emission to air } & $\begin{array}{l}\text { Coal supply } \\
\text { chain }\end{array}$ & $\begin{array}{l}\text { Underground } \\
\text { mining }\end{array}$ & Transport & $\begin{array}{l}\text { Power } \\
\text { plant }\end{array}$ \\
\hline \multirow{63}{*}{ 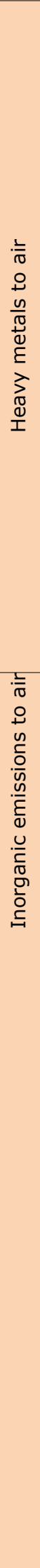 } & Antimony & $3.21 \mathrm{E}-05$ & $2.28 \mathrm{E}-05$ & $0.00 \mathrm{E}+00$ & $9.22 \mathrm{E}-06$ \\
\hline & Arsenic (+V) & $6.82 \mathrm{E}-05$ & $1.77 \mathrm{E}-05$ & $0.00 \mathrm{E}+00$ & $5.06 \mathrm{E}-05$ \\
\hline & Arsenic trioxide & $2.22 \mathrm{E}-12$ & 9.25E-13 & $0.00 \mathrm{E}+00$ & $1.29 \mathrm{E}-12$ \\
\hline & Cadmium (+II) & 8.34E-06 & $3.46 \mathrm{E}-06$ & $0.00 \mathrm{E}+00$ & $4.88 \mathrm{E}-06$ \\
\hline & Chromium (+III) & $1.11 \mathrm{E}-08$ & $8.31 \mathrm{E}-10$ & $0.00 \mathrm{E}+00$ & $1.03 \mathrm{E}-08$ \\
\hline & Chromium (unspecified) & $2.34 \mathrm{E}-05$ & $1.05 \mathrm{E}-05$ & $0.00 \mathrm{E}+00$ & $1.30 \mathrm{E}-05$ \\
\hline & Cobalt & $1.78 \mathrm{E}-05$ & $1.30 \mathrm{E}-05$ & $0.00 \mathrm{E}+00$ & $4.81 \mathrm{E}-06$ \\
\hline & Copper (+II) & $1.41 \mathrm{E}-05$ & $5.30 \mathrm{E}-06$ & $0.00 \mathrm{E}+00$ & $8.79 \mathrm{E}-06$ \\
\hline & Heavy metals to air (unspecified) & $2.18 \mathrm{E}-09$ & $6.04 \mathrm{E}-12$ & $0.00 \mathrm{E}+00$ & $2.17 \mathrm{E}-09$ \\
\hline & Hydrogen arsenic (arsine) & $1.84 \mathrm{E}-10$ & $7.68 \mathrm{E}-11$ & $0.00 \mathrm{E}+00$ & $1.07 \mathrm{E}-10$ \\
\hline & Iron & $1.95 \mathrm{E}-06$ & $7.21 \mathrm{E}-07$ & $0.00 \mathrm{E}+00$ & $1.23 \mathrm{E}-06$ \\
\hline & Lanthanides & $4.91 \mathrm{E}-10$ & $2.54 \mathrm{E}-10$ & $0.00 \mathrm{E}+00$ & $2.38 \mathrm{E}-10$ \\
\hline & Lead (+II) & $1.39 \mathrm{E}-04$ & $4.69 E-05$ & $0.00 \mathrm{E}+00$ & $9.23 \mathrm{E}-05$ \\
\hline & Manganese (+II) & $7.08 \mathrm{E}-05$ & $1.40 \mathrm{E}-05$ & $0.00 \mathrm{E}+00$ & $5.68 \mathrm{E}-05$ \\
\hline & Mercury (+II) & $2.04 \mathrm{E}-05$ & $1.13 \mathrm{E}-06$ & $0.00 \mathrm{E}+00$ & $1.92 \mathrm{E}-05$ \\
\hline & Molybdenum & 7.79E-08 & $4.05 E-08$ & $0.00 \mathrm{E}+00$ & $3.74 \mathrm{E}-08$ \\
\hline & Nickel (+II) & $3.90 \mathrm{E}-05$ & $2.73 \mathrm{E}-05$ & $0.00 \mathrm{E}+00$ & $1.17 \mathrm{E}-05$ \\
\hline & Palladium & $3.73 \mathrm{E}-16$ & $8.58 \mathrm{E}-17$ & $0.00 \mathrm{E}+00$ & $2.87 \mathrm{E}-16$ \\
\hline & Rhodium & $3.60 \mathrm{E}-16$ & $8.28 \mathrm{E}-17$ & $0.00 \mathrm{E}+00$ & $2.77 \mathrm{E}-16$ \\
\hline & Selenium & $2.16 \mathrm{E}-04$ & $6.02 \mathrm{E}-05$ & $0.00 \mathrm{E}+00$ & $1.56 \mathrm{E}-04$ \\
\hline & Silver & $1.25 \mathrm{E}-15$ & $1.01 \mathrm{E}-15$ & $0.00 \mathrm{E}+00$ & $2.39 \mathrm{E}-16$ \\
\hline & Tellurium & $1.48 \mathrm{E}-09$ & $1.11 \mathrm{E}-10$ & $0.00 \mathrm{E}+00$ & $1.37 \mathrm{E}-09$ \\
\hline & Thallium & $1.08 \mathrm{E}-08$ & $7.45 \mathrm{E}-10$ & $0.00 \mathrm{E}+00$ & $1.01 \mathrm{E}-08$ \\
\hline & Tin (+IV) & $6.26 \mathrm{E}-05$ & $2.44 \mathrm{E}-06$ & $0.00 \mathrm{E}+00$ & $6.02 \mathrm{E}-05$ \\
\hline & Titanium & $3.84 \mathrm{E}-08$ & $1.27 \mathrm{E}-08$ & $0.00 \mathrm{E}+00$ & $2.56 \mathrm{E}-08$ \\
\hline & Vanadium (+III) & $1.10 \mathrm{E}-04$ & $9.23 E-05$ & $0.00 \mathrm{E}+00$ & $1.79 \mathrm{E}-05$ \\
\hline & Zinc (+II) & $3.25 \mathrm{E}-04$ & $1.15 \mathrm{E}-04$ & $0.00 \mathrm{E}+00$ & $2.09 E-04$ \\
\hline & Ammonia & $6.56 \mathrm{E}-03$ & $2.50 \mathrm{E}-04$ & $0.00 \mathrm{E}+00$ & $6.31 \mathrm{E}-03$ \\
\hline & Ammonium & $1.34 \mathrm{E}-10$ & $4.99 \mathrm{E}-13$ & $0.00 \mathrm{E}+00$ & $1.33 \mathrm{E}-10$ \\
\hline & Ammonium nitrate & $7.75 \mathrm{E}-11$ & $1.05 \mathrm{E}-11$ & $0.00 \mathrm{E}+00$ & $6.69 \mathrm{E}-11$ \\
\hline & Barium & $1.82 \mathrm{E}-04$ & $7.66 \mathrm{E}-05$ & $0.00 \mathrm{E}+00$ & $1.06 \mathrm{E}-04$ \\
\hline & Beryllium & $1.41 \mathrm{E}-06$ & $7.00 \mathrm{E}-07$ & $0.00 \mathrm{E}+00$ & $7.13 \mathrm{E}-07$ \\
\hline & Boron compounds (unspecified) & $1.80 \mathrm{E}-03$ & $1.85 \mathrm{E}-04$ & $0.00 \mathrm{E}+00$ & $1.62 \mathrm{E}-03$ \\
\hline & Bromine & $1.00 \mathrm{E}-03$ & $2.21 \mathrm{E}-04$ & $0.00 \mathrm{E}+00$ & $7.81 \mathrm{E}-04$ \\
\hline & Carbon dioxide & $9.73 E+02$ & $5.03 \mathrm{E}+01$ & $1.20 \mathrm{E}+01$ & $9.10 \mathrm{E}+02$ \\
\hline & Carbon dioxide (biotic) & $1.47 \mathrm{E}+00$ & $7.50 \mathrm{E}-01$ & $0.00 \mathrm{E}+00$ & $7.20 \mathrm{E}-01$ \\
\hline & Carbon disulphide & $1.81 \mathrm{E}-08$ & $1.19 \mathrm{E}-09$ & $0.00 \mathrm{E}+00$ & $1.69 \mathrm{E}-08$ \\
\hline & Carbon monoxide & $2.98 \mathrm{E}-01$ & $1.11 \mathrm{E}-01$ & $1.90 \mathrm{E}-02$ & $1.68 \mathrm{E}-01$ \\
\hline & Chloride (unspecified) & $1.82 \mathrm{E}-05$ & $9.86 \mathrm{E}-06$ & $0.00 \mathrm{E}+00$ & $8.38 \mathrm{E}-06$ \\
\hline & Chlorine & $3.82 \mathrm{E}-09$ & $1.72 \mathrm{E}-10$ & $0.00 \mathrm{E}+00$ & $3.65 \mathrm{E}-09$ \\
\hline & Cyanide (unspecified) & $3.80 \mathrm{E}-07$ & $2.00 \mathrm{E}-07$ & $0.00 \mathrm{E}+00$ & $1.81 \mathrm{E}-07$ \\
\hline & Fluoride & $1.10 \mathrm{E}-05$ & $5.20 \mathrm{E}-06$ & $0.00 \mathrm{E}+00$ & $5.78 \mathrm{E}-06$ \\
\hline & Fluorine & $4.24 \mathrm{E}-10$ & $1.19 \mathrm{E}-10$ & $0.00 \mathrm{E}+00$ & $3.05 \mathrm{E}-10$ \\
\hline & Helium & $2.19 \mathrm{E}-06$ & $1.26 \mathrm{E}-06$ & $0.00 \mathrm{E}+00$ & $9.26 \mathrm{E}-07$ \\
\hline & Hydrogen & 4.77E-04 & $4.46 \mathrm{E}-06$ & $0.00 \mathrm{E}+00$ & $4.72 \mathrm{E}-04$ \\
\hline & Hydrogen bromine (hydrobromic acid) & $2.66 \mathrm{E}-08$ & $1.96 \mathrm{E}-10$ & $0.00 \mathrm{E}+00$ & $2.64 \mathrm{E}-08$ \\
\hline & Hydrogen chloride & $1.43 \mathrm{E}-02$ & $6.31 \mathrm{E}-03$ & $0.00 \mathrm{E}+00$ & 7.97E-03 \\
\hline & Hydrogen cyanide (prussic acid) & $3.38 \mathrm{E}-08$ & $2.25 \mathrm{E}-09$ & $0.00 \mathrm{E}+00$ & $3.15 \mathrm{E}-08$ \\
\hline & Hydrogen fluoride & $3.45 \mathrm{E}-03$ & $1.75 \mathrm{E}-03$ & $0.00 \mathrm{E}+00$ & $1.70 \mathrm{E}-03$ \\
\hline & Hydrogen iodide & $2.91 \mathrm{E}-11$ & $1.14 \mathrm{E}-13$ & $0.00 \mathrm{E}+00$ & $2.90 \mathrm{E}-11$ \\
\hline & Hydrogen phosphorous & $1.20 \mathrm{E}-11$ & $9.32 \mathrm{E}-12$ & $0.00 \mathrm{E}+00$ & $2.65 \mathrm{E}-12$ \\
\hline & Hydrogen sulphide & 8.93E-05 & $2.45 \mathrm{E}-05$ & $0.00 \mathrm{E}+00$ & $6.48 \mathrm{E}-05$ \\
\hline & Lead dioxide & $1.31 \mathrm{E}-11$ & $1.06 \mathrm{E}-11$ & $0.00 \mathrm{E}+00$ & $2.50 \mathrm{E}-12$ \\
\hline & Nitrogen (atmospheric nitrogen) & 9.99E-02 & $2.38 \mathrm{E}-02$ & $0.00 \mathrm{E}+00$ & $7.62 \mathrm{E}-02$ \\
\hline & Nitrogen dioxide & $5.06 \mathrm{E}-14$ & $0.00 \mathrm{E}+00$ & $0.00 \mathrm{E}+00$ & $5.06 \mathrm{E}-14$ \\
\hline & Nitrogen monoxide & $1.80 \mathrm{E}-09$ & $1.26 \mathrm{E}-10$ & $0.00 \mathrm{E}+00$ & 1.67E-09 \\
\hline & Nitrogen oxides & $1.43 \mathrm{E}+00$ & $4.01 \mathrm{E}-01$ & $7.98 \mathrm{E}-02$ & $9.54 \mathrm{E}-01$ \\
\hline & Nitrous oxide (laughing gas) & $4.04 \mathrm{E}-02$ & 7.47E-04 & 2.99E-04 & $3.93 E-02$ \\
\hline & Oxygen & $9.78 \mathrm{E}-02$ & $6.03 E-02$ & $0.00 \mathrm{E}+00$ & $3.75 \mathrm{E}-02$ \\
\hline & Scandium & $1.97 \mathrm{E}-10$ & $1.27 \mathrm{E}-10$ & $0.00 \mathrm{E}+00$ & $7.00 \mathrm{E}-11$ \\
\hline & Steam & $1.67 \mathrm{E}-03$ & $4.70 \mathrm{E}-04$ & $0.00 \mathrm{E}+00$ & $1.62 \mathrm{E}-03$ \\
\hline & Strontium & $8.78 \mathrm{E}-09$ & 5.06E-09 & $0.00 \mathrm{E}+00$ & $3.72 \mathrm{E}-09$ \\
\hline & Sulphur dioxide & $1.19 \mathrm{E}+00$ & $3.67 \mathrm{E}-01$ & $2.64 \mathrm{E}-03$ & $8.20 \mathrm{E}-01$ \\
\hline
\end{tabular}




\begin{tabular}{|c|c|c|c|c|c|}
\hline \multicolumn{2}{|c|}{ Emission to air } & $\begin{array}{l}\text { Coal supply } \\
\text { chain }\end{array}$ & $\begin{array}{c}\text { Underground } \\
\text { mining }\end{array}$ & Transport & $\begin{array}{l}\text { Power } \\
\text { plant }\end{array}$ \\
\hline \multirow{67}{*}{ 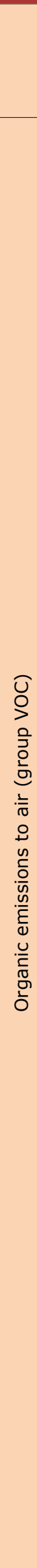 } & Sulphur hexafluoride & $8.92 E-10$ & $7.21 \mathrm{E}-10$ & $0.00 \mathrm{E}+00$ & $1.71 \mathrm{E}-10$ \\
\hline & Sulphuric acid & $5.78 \mathrm{E}-08$ & 7.34E-09 & $0.00 \mathrm{E}+00$ & $5.05 \mathrm{E}-08$ \\
\hline & Tin oxide & $1.14 \mathrm{E}-12$ & $9.20 \mathrm{E}-13$ & $0.00 \mathrm{E}+00$ & $2.17 \mathrm{E}-13$ \\
\hline & Zinc oxide & $2.27 \mathrm{E}-12$ & $1.84 \mathrm{E}-12$ & $0.00 \mathrm{E}+00$ & $4.34 \mathrm{E}-13$ \\
\hline & Zinc sulphate & $3.88 \mathrm{E}-09$ & $1.62 \mathrm{E}-09$ & $0.00 \mathrm{E}+00$ & $2.26 \mathrm{E}-09$ \\
\hline & Anthracene & $2.67 \mathrm{E}-10$ & $1.12 \mathrm{E}-10$ & $0.00 \mathrm{E}+00$ & $1.55 \mathrm{E}-10$ \\
\hline & Benzo $\{a\}$ anthracene & $1.34 \mathrm{E}-10$ & $5.64 \mathrm{E}-11$ & $0.00 \mathrm{E}+00$ & $7.80 \mathrm{E}-11$ \\
\hline & Benzo $\{a\}$ pyrene & $6.37 E-08$ & $5.23 E-09$ & $0.00 \mathrm{E}+00$ & 5.84E-08 \\
\hline & Benzo\{ghi\}perylene & $1.20 \mathrm{E}-10$ & $5.03 E-11$ & $0.00 \mathrm{E}+00$ & $6.95 \mathrm{E}-11$ \\
\hline & Benzofluoranthene & $2.40 \mathrm{E}-10$ & $1.01 \mathrm{E}-10$ & $0.00 \mathrm{E}+00$ & $1.39 \mathrm{E}-10$ \\
\hline & Chrysene & $3.30 \mathrm{E}-10$ & $1.39 \mathrm{E}-10$ & $0.00 \mathrm{E}+00$ & $1.91 \mathrm{E}-10$ \\
\hline & Dibenz(a)anthracene & $7.47 \mathrm{E}-11$ & $3.14 \mathrm{E}-11$ & $0.00 \mathrm{E}+00$ & $4.33 \mathrm{E}-11$ \\
\hline & Indenopyrene & $8.92 \mathrm{E}-11$ & $3.74 \mathrm{E}-11$ & $0.00 \mathrm{E}+00$ & $5.18 \mathrm{E}-11$ \\
\hline & Naphthalene & $2.80 \mathrm{E}-08$ & $1.18 \mathrm{E}-08$ & $0.00 \mathrm{E}+00$ & $1.63 \mathrm{E}-08$ \\
\hline & Phenanthrene & $8.81 \mathrm{E}-09$ & $3.70 \mathrm{E}-09$ & $0.00 \mathrm{E}+00$ & $5.11 \mathrm{E}-09$ \\
\hline & Polycyclic aromatic hydrocarbons (PAH) & $1.27 \mathrm{E}-05$ & $1.58 \mathrm{E}-06$ & $0.00 \mathrm{E}+00$ & $1.11 \mathrm{E}-05$ \\
\hline & Dichloromethane (methylene chloride) & $5.21 \mathrm{E}-15$ & $1.20 \mathrm{E}-15$ & $0.00 \mathrm{E}+00$ & $4.01 \mathrm{E}-15$ \\
\hline & Halogenated hydrocarbons (unspecified) & $2.86 \mathrm{E}-15$ & $8.30 \mathrm{E}-16$ & $0.00 \mathrm{E}+00$ & $2.03 E-15$ \\
\hline & Polychlorinated biphenyls (PCB unspecified) & $3.96 \mathrm{E}-10$ & $1.40 \mathrm{E}-10$ & $0.00 \mathrm{E}+00$ & $2.56 \mathrm{E}-10$ \\
\hline & Polychlorinated dibenzo-p-dioxins $(2,3,7,8$ - TCDD $)$ & $5.20 \mathrm{E}-11$ & $1.91 \mathrm{E}-12$ & $0.00 \mathrm{E}+00$ & $5.01 \mathrm{E}-11$ \\
\hline & R 11 (trichlorofluoromethane) & $5.71 \mathrm{E}-07$ & $8.27 E-08$ & $0.00 \mathrm{E}+00$ & $4.88 \mathrm{E}-07$ \\
\hline & R 114 (dichlorotetrafluoroethane) & $5.84 \mathrm{E}-07$ & $8.47 \mathrm{E}-08$ & $0.00 \mathrm{E}+00$ & $5.00 \mathrm{E}-07$ \\
\hline & R 12 (dichlorodifluoromethane) & $1.23 \mathrm{E}-07$ & $1.78 \mathrm{E}-08$ & $0.00 \mathrm{E}+00$ & $1.05 \mathrm{E}-07$ \\
\hline & R 13 (chlorotrifluoromethane) & $7.70 \mathrm{E}-08$ & $1.12 \mathrm{E}-08$ & $0.00 \mathrm{E}+00$ & $6.59 \mathrm{E}-08$ \\
\hline & R 22 (chlorodifluoromethane) & $1.34 \mathrm{E}-07$ & $1.94 \mathrm{E}-08$ & $0.00 \mathrm{E}+00$ & $1.15 \mathrm{E}-07$ \\
\hline & Tetrafluoromethane & 3.69E-09 & 1.17E-09 & $0.00 \mathrm{E}+00$ & $2.52 \mathrm{E}-09$ \\
\hline & Vinyl chloride (VCM; chloroethene) & $6.69 \mathrm{E}-08$ & $3.09 E-08$ & $0.00 \mathrm{E}+00$ & $3.60 \mathrm{E}-08$ \\
\hline & Acetaldehyde (Ethanal) & $4.41 \mathrm{E}-06$ & $3.05 E-06$ & $0.00 \mathrm{E}+00$ & $1.36 \mathrm{E}-06$ \\
\hline & Acetic acid & $1.71 \mathrm{E}-05$ & $1.11 \mathrm{E}-05$ & $0.00 \mathrm{E}+00$ & $6.04 \mathrm{E}-06$ \\
\hline & Acetone (dimethylcetone) & $4.30 \mathrm{E}-06$ & $3.01 \mathrm{E}-06$ & $0.00 \mathrm{E}+00$ & $1.29 \mathrm{E}-06$ \\
\hline & Acrolein & $1.88 \mathrm{E}-09$ & $7.91 \mathrm{E}-10$ & $0.00 \mathrm{E}+00$ & $1.09 \mathrm{E}-09$ \\
\hline & Aldehyde (unspecified) & $3.93 \mathrm{E}-07$ & $2.11 \mathrm{E}-07$ & $0.00 \mathrm{E}+00$ & $1.82 \mathrm{E}-07$ \\
\hline & Alkane (unspecified) & $3.73 E-03$ & $3.56 \mathrm{E}-04$ & $0.00 \mathrm{E}+00$ & 3.37E-03 \\
\hline & Alkene (unspecified) & $3.72 E-03$ & $3.46 \mathrm{E}-04$ & $0.00 \mathrm{E}+00$ & $3.37 \mathrm{E}-03$ \\
\hline & Aromatic hydrocarbons (unspecified) & $1.44 \mathrm{E}-06$ & $1.07 \mathrm{E}-06$ & $0.00 \mathrm{E}+00$ & $3.70 \mathrm{E}-07$ \\
\hline & Benzene & $2.47 \mathrm{E}-05$ & $7.81 \mathrm{E}-06$ & $0.00 \mathrm{E}+00$ & $1.69 \mathrm{E}-05$ \\
\hline & Butadiene & $1.32 \mathrm{E}-10$ & $3.66 \mathrm{E}-13$ & $0.00 \mathrm{E}+00$ & $1.32 \mathrm{E}-10$ \\
\hline & Butane & 7.37E-04 & $3.64 \mathrm{E}-04$ & $0.00 \mathrm{E}+00$ & $3.74 \mathrm{E}-04$ \\
\hline & Butane (n-butane) & $3.58 \mathrm{E}-04$ & $3.37 E-05$ & $0.00 \mathrm{E}+00$ & $3.24 \mathrm{E}-04$ \\
\hline & Cyclohexane (hexahydro benzene) & $4.15 \mathrm{E}-07$ & $2.73 E-08$ & $0.00 \mathrm{E}+00$ & $3.88 \mathrm{E}-07$ \\
\hline & Diethylamine & $3.35 \mathrm{E}-15$ & $1.25 \mathrm{E}-17$ & $0.00 \mathrm{E}+00$ & $3.33 \mathrm{E}-15$ \\
\hline & Ethane & $2.73 E-03$ & $1.04 \mathrm{E}-03$ & $0.00 \mathrm{E}+00$ & $1.70 \mathrm{E}-03$ \\
\hline & Ethanol & $7.62 \mathrm{E}-06$ & $5.43 E-06$ & $0.00 \mathrm{E}+00$ & $2.18 \mathrm{E}-06$ \\
\hline & Ethene (ethylene) & $2.39 \mathrm{E}-07$ & $1.11 \mathrm{E}-07$ & $0.00 \mathrm{E}+00$ & $1.29 \mathrm{E}-07$ \\
\hline & Ethyl benzene & $3.72 \mathrm{E}-03$ & $3.45 E-04$ & $0.00 \mathrm{E}+00$ & $3.37 \mathrm{E}-03$ \\
\hline & Fluoranthene & $8.70 \mathrm{E}-10$ & $3.65 \mathrm{E}-10$ & $0.00 \mathrm{E}+00$ & $5.05 \mathrm{E}-10$ \\
\hline & Fluorene & $2.76 \mathrm{E}-09$ & $1.16 \mathrm{E}-09$ & $0.00 \mathrm{E}+00$ & $1.60 \mathrm{E}-09$ \\
\hline & Formaldehyde (methanal) & $1.04 \mathrm{E}-03$ & $1.04 \mathrm{E}-04$ & $0.00 \mathrm{E}+00$ & $9.38 \mathrm{E}-04$ \\
\hline & Heptane (isomers) & $2.33 \mathrm{E}-05$ & $1.26 \mathrm{E}-05$ & $0.00 \mathrm{E}+00$ & $1.07 \mathrm{E}-05$ \\
\hline & Hexamethylene diamine (HMDA) & $7.76 \mathrm{E}-12$ & $2.15 \mathrm{E}-14$ & $0.00 \mathrm{E}+00$ & $7.74 \mathrm{E}-12$ \\
\hline & Hexane (isomers) & $3.53 \mathrm{E}-05$ & $1.88 \mathrm{E}-05$ & $0.00 \mathrm{E}+00$ & $1.66 \mathrm{E}-05$ \\
\hline & Mercaptan (unspecified) & $8.83 \mathrm{E}-07$ & $4.09 E-07$ & $0.00 \mathrm{E}+00$ & $4.74 \mathrm{E}-07$ \\
\hline & Methanol & $7.23 \mathrm{E}-06$ & $5.38 \mathrm{E}-06$ & $0.00 \mathrm{E}+00$ & $1.85 \mathrm{E}-06$ \\
\hline & NMVOC (unspecified) & $5.59 \mathrm{E}-02$ & $3.24 \mathrm{E}-02$ & $0.00 \mathrm{E}+00$ & $2.35 \mathrm{E}-02$ \\
\hline & Octane & $1.28 \mathrm{E}-05$ & $6.94 \mathrm{E}-06$ & $0.00 \mathrm{E}+00$ & $5.90 \mathrm{E}-06$ \\
\hline & Pentane (n-pentane) & $2.65 E-03$ & $3.45 E-04$ & $0.00 \mathrm{E}+00$ & $2.30 \mathrm{E}-03$ \\
\hline & Phenol (hydroxy benzene) & $9.95 \mathrm{E}-11$ & $5.67 \mathrm{E}-11$ & $0.00 \mathrm{E}+00$ & $4.27 \mathrm{E}-11$ \\
\hline & Propane & 4.09E-03 & $1.81 \mathrm{E}-03$ & $0.00 \mathrm{E}+00$ & $2.27 E-03$ \\
\hline & Propene (propylene) & $3.38 \mathrm{E}-04$ & $3.14 \mathrm{E}-05$ & $0.00 \mathrm{E}+00$ & $3.06 \mathrm{E}-04$ \\
\hline & Propionic acid (propane acid) & $5.52 \mathrm{E}-10$ & $2.67 \mathrm{E}-10$ & $0.00 \mathrm{E}+00$ & $2.84 \mathrm{E}-10$ \\
\hline & Styrene & $4.59 \mathrm{E}-10$ & $3.03 E-11$ & $0.00 \mathrm{E}+00$ & $4.29 \mathrm{E}-10$ \\
\hline & Toluene (methyl benzene) & $1.69 \mathrm{E}-03$ & $1.57 \mathrm{E}-04$ & $0.00 \mathrm{E}+00$ & $1.53 \mathrm{E}-03$ \\
\hline & Trimethylbenzene & $1.11 \mathrm{E}-11$ & $8.96 \mathrm{E}-12$ & $0.00 \mathrm{E}+00$ & $2.12 \mathrm{E}-12$ \\
\hline & Xylene (dimethyl benzene) & $1.55 \mathrm{E}-02$ & $1.44 \mathrm{E}-03$ & $0.00 \mathrm{E}+00$ & $1.41 \mathrm{E}-02$ \\
\hline & Methane & $3.81 \mathrm{E}+00$ & $3.58 \mathrm{E}+00$ & $1.93 \mathrm{E}-01$ & $3.72 \mathrm{E}-02$ \\
\hline & Organic chlorine compounds & $3.88 \mathrm{E}-11$ & $5.27 \mathrm{E}-12$ & $0.00 \mathrm{E}+00$ & $3.35 \mathrm{E}-11$ \\
\hline & VOC (unspecified) & $3.95 E-03$ & $2.02 \mathrm{E}-06$ & $3.94 \mathrm{E}-03$ & $3.28 \mathrm{E}-06$ \\
\hline
\end{tabular}




\begin{tabular}{|c|c|c|c|c|c|}
\hline \multicolumn{2}{|r|}{ Emission to air } & \multirow{2}{*}{$\begin{array}{c}\text { Coal supply } \\
\text { chain }\end{array}$} & \multirow{2}{*}{$\begin{array}{c}\begin{array}{c}\text { Underground } \\
\text { mining }\end{array} \\
1.27 \mathrm{E}-03 \\
\end{array}$} & \multirow{2}{*}{$\begin{array}{l}\text { Transport } \\
0.00 E+00\end{array}$} & \multirow{2}{*}{$\begin{array}{c}\begin{array}{c}\text { Power } \\
\text { plant }\end{array} \\
3.68 \mathrm{E}-03\end{array}$} \\
\hline \multirow{5}{*}{ 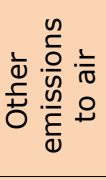 } & Exhaust & & & & \\
\hline & non used primary energy from wind power & $0.00 \mathrm{E}+00$ & $0.00 \mathrm{E}+00$ & $0.00 \mathrm{E}+00$ & $0.00 \mathrm{E}+00$ \\
\hline & Unused primary energy from solar energy & $0.00 \mathrm{E}+00$ & $0.00 E+00$ & $0.00 E+00$ & $0.00 E+00$ \\
\hline & Used air & $2.68 \mathrm{E}+00$ & $2.77 \mathrm{E}-01$ & $0.00 E+00$ & $2.41 E+00$ \\
\hline & Waste heat & $0.00 \mathrm{E}+00$ & $0.00 \mathrm{E}+00$ & $0.00 \mathrm{E}+00$ & $0.00 E+00$ \\
\hline \multirow{6}{*}{ 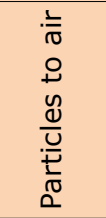 } & Dust (PM10) & $1.06 \mathrm{E}-02$ & $5.90 E-03$ & $0.00 E+00$ & $4.72 \mathrm{E}-03$ \\
\hline & Dust (PM2,5 - PM10) & $1.38 \mathrm{E}-03$ & $0.00 \mathrm{E}+00$ & $1.38 \mathrm{E}-03$ & $0.00 E+00$ \\
\hline & Dust (PM2.5) & $8.51 \mathrm{E}-02$ & 4.79E-02 & $0.00 \mathrm{E}+00$ & $3.72 \mathrm{E}-02$ \\
\hline & Dust (unspecified) & $1.49 \mathrm{E}-01$ & 7.90E-02 & $0.00 \mathrm{E}+00$ & $7.04 \mathrm{E}-02$ \\
\hline & Metals (unspecified) & $3.81 \mathrm{E}-10$ & $2.99 \mathrm{E}-10$ & $0.00 E+00$ & 8.20E-11 \\
\hline & Wood (dust) & $4.20 E-10$ & $3.40 \mathrm{E}-10$ & $0.00 E+00$ & $8.02 E-11$ \\
\hline \multirow{25}{*}{ 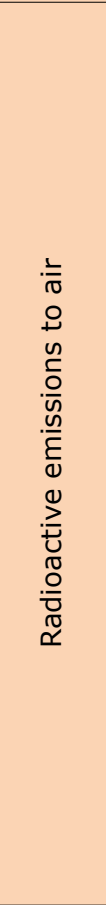 } & Antimony (Sb124) & $0.00 \mathrm{E}+00$ & $0.00 \mathrm{E}+00$ & $0.00 \mathrm{E}+00$ & $0.00 E+00$ \\
\hline & Argon (Ar41) & $0.00 \mathrm{E}+00$ & $0.00 E+00$ & $0.00 E+00$ & $0.00 E+00$ \\
\hline & Carbon (C14) & $0.00 \mathrm{E}+00$ & $0.00 \mathrm{E}+00$ & $0.00 E+00$ & $0.00 E+00$ \\
\hline & Cesium (Cs134) & $0.00 \mathrm{E}+00$ & $0.00 \mathrm{E}+00$ & $0.00 \mathrm{E}+00$ & $0.00 \mathrm{E}+00$ \\
\hline & Cesium (Cs137) & $0.00 \mathrm{E}+00$ & $0.00 E+00$ & $0.00 E+00$ & $0.00 E+00$ \\
\hline & Cobalt (Co58) & $0.00 \mathrm{E}+00$ & $0.00 \mathrm{E}+00$ & $0.00 \mathrm{E}+00$ & $0.00 \mathrm{E}+00$ \\
\hline & Cobalt (Co60) & $0.00 \mathrm{E}+00$ & $0.00 E+00$ & $0.00 E+00$ & $0.00 E+00$ \\
\hline & Hydrogen (H3) & $0.00 \mathrm{E}+00$ & $0.00 \mathrm{E}+00$ & $0.00 E+00$ & $0.00 E+00$ \\
\hline & Iodine (I129) & $0.00 \mathrm{E}+00$ & $0.00 \mathrm{E}+00$ & $0.00 \mathrm{E}+00$ & $0.00 \mathrm{E}+00$ \\
\hline & Iodine (I131) & $0.00 \mathrm{E}+00$ & $0.00 \mathrm{E}+00$ & $0.00 E+00$ & $0.00 E+00$ \\
\hline & Krypton (Kr85) & $0.00 \mathrm{E}+00$ & $0.00 \mathrm{E}+00$ & $0.00 \mathrm{E}+00$ & $0.00 \mathrm{E}+00$ \\
\hline & Krypton (Kr85m) & $0.00 \mathrm{E}+00$ & $0.00 \mathrm{E}+00$ & $0.00 \mathrm{E}+00$ & $0.00 E+00$ \\
\hline & Plutonium (Pu alpha) & $0.00 \mathrm{E}+00$ & $0.00 \mathrm{E}+00$ & $0.00 \mathrm{E}+00$ & $0.00 E+00$ \\
\hline & Radon (Rn222) & $0.00 \mathrm{E}+00$ & $0.00 \mathrm{E}+00$ & $0.00 \mathrm{E}+00$ & $0.00 \mathrm{E}+00$ \\
\hline & Uranium (total) & $7.25 \mathrm{E}-07$ & $1.02 \mathrm{E}-07$ & $0.00 \mathrm{E}+00$ & $6.23 E-07$ \\
\hline & Uranium (U234) & $0.00 \mathrm{E}+00$ & $0.00 \mathrm{E}+00$ & $0.00 \mathrm{E}+00$ & $0.00 \mathrm{E}+00$ \\
\hline & Uranium (U235) & $0.00 \mathrm{E}+00$ & $0.00 \mathrm{E}+00$ & $0.00 \mathrm{E}+00$ & $0.00 \mathrm{E}+00$ \\
\hline & Uranium (U238) & $0.00 \mathrm{E}+00$ & $0.00 \mathrm{E}+00$ & $0.00 \mathrm{E}+00$ & $0.00 \mathrm{E}+00$ \\
\hline & Xenon (Xe131m) & $0.00 \mathrm{E}+00$ & $0.00 E+00$ & $0.00 E+00$ & $0.00 E+00$ \\
\hline & Xenon (Xe133) & $0.00 \mathrm{E}+00$ & $0.00 \mathrm{E}+00$ & $0.00 \mathrm{E}+00$ & $0.00 E+00$ \\
\hline & Xenon (Xe133m) & $0.00 \mathrm{E}+00$ & $0.00 \mathrm{E}+00$ & $0.00 \mathrm{E}+00$ & $0.00 \mathrm{E}+00$ \\
\hline & Xenon (Xe135) & $0.00 \mathrm{E}+00$ & $0.00 E+00$ & $0.00 E+00$ & $0.00 E+00$ \\
\hline & Xenon (Xe135m) & $0.00 \mathrm{E}+00$ & $0.00 E+00$ & $0.00 \mathrm{E}+00$ & $0.00 E+00$ \\
\hline & Xenon (Xe137) & $0.00 \mathrm{E}+00$ & $0.00 \mathrm{E}+00$ & $0.00 \mathrm{E}+00$ & $0.00 \mathrm{E}+00$ \\
\hline & Xenon (Xe138) & $0.00 \mathrm{E}+00$ & $0.00 \mathrm{E}+00$ & $0.00 E+00$ & $0.00 E+00$ \\
\hline
\end{tabular}

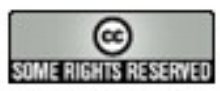

Article's contents are provided on a Attribution-Non Commercial 3.0 Creative commons license. Readers are allowed to copy, distribute and communicate article's contents, provided the author's and Journal of Industrial Engineering and Management's names are included. It must not be used for commercial purposes. To see the complete license contents, please visit http://creativecommons.org/licenses/by-nc/3.0/. 